Linköping Studies in Science and

Technology, Thesis No. 1659

LIU-TEK-LIC-2014:92

\title{
Towards a Framework for Production Strategy in Construction
}

\author{
Henric Jonsson
}

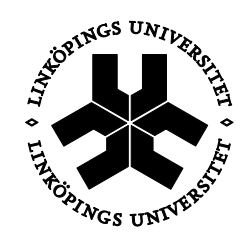

\section{Linköping University}

Department of Science and Technology

Linköping University

SE-601 74 Norrköping, Sweden

Norrköping 2014 
Towards a Framework for Production Strategy in Construction

(CHenric Jonsson, 2014

Printed in Sweden by LiU-Tryck, Linköping, Sweden, 2014

ISBN: 978-91-7519-333-5

ISSN 0280-7971

Thesis No. 1659

LIU-TEK-LIC-2014:92 


\section{Abstract}

The problem with low productivity increase in the construction industry is highlighted in many studies and in Sweden the need to improve productivity and client satisfaction in the construction industry has promoted a number of government investigations. One suggested way of improving productivity and client satisfaction is to move value adding activities off-site, to a more industrial environment. Compared to traditional on-site production, off-site production has been said to have many advantages such as: higher productivity, lower production cost, higher quality and shorter lead times. The trade-off when increasing the degree of off-site production is the reduced product and process flexibility. The trade-off between productivity and flexibility indicates that different production systems perform well in different areas of competition.

The purpose of this research is to develop a production strategy framework for the construction industry, and more specifically for the production of multifamily residences. This framework can help construction firms to design the production system and find the right balance between productivity and flexibility. For the manufacturing industry, production strategy frameworks have been developed and shown useful when designing new or redesigning existing production systems. A corresponding framework adapted to the construction industry would be useful for construction firms when designing production systems to meet the targeted market in the most efficient way.

Production strategy theory is traditionally built around two broad groups, decision categories and competitive priorities. Decision categories are areas in which a company must make decisions that are of long term importance for the production function. In this thesis focus is on the decision category traditionally named product/process technology and more specifically on the so called process choice i.e. choosing a production system that meets the demands from the targeted market in the most efficient way. To do this a classification matrix is developed that classify production systems along two dimensions,

the degree of off-site assembly in one dimension and the degree of product standardisation in the other. This way of visualising the process and product characteristic has been used before, in traditional production strategy frameworks, to facilitate the process choice.

For the classification matrix to be useful, the positions in the suggested classification matrix must be linked to the ability of different production systems to deliver manufacturing outputs. Therefor a performance measurement system is developed. In the process of developing classification matrix and the performance measurement system three research questions are addressed: 
RQ1. What dimensions can be useful, from a production strategy perspective, when classifying different production systems for the production of multifamily residences?

RQ2. What manufacturing outputs/competitive priorities have to be taken into consideration when evaluating different production systems for production of multifamily residences?

RQ3. How should the ability of a production system to deliver manufacturing outputs be measured?

To answer the research questions an abductive approach has been used. The results from a literature review have been used to develop theoretical constructs. Case studies have then been used to empirically test the constructs. Thereafter the empirical data and information from additional literature reviews has then been used to further develop and refine the theoretical constructs. The findings of this research are thereby grounded in both theory and practise.

There are two main contributions in this thesis. The first one is the proposed classification matrix for production systems producing multifamily residences. The classification matrix can be used as a base for production strategy reasoning in the construction industry. The second contribution is the suggested performance measurement system in which KPIs for measuring quality, delivery (speed and dependability), cost (level and dependability) and flexibility (volume, mix and expansion) have been defined.

By positioning different production systems in the classification matrix and then use the defined performance measurement system, relative differences between the ability of different production systems to deliver manufacturing outputs can be exposed. The classification matrix can help companies to work with production strategy in a structured way, and to visualize the link between the market strategy and the production function of the firm in order to meet the demands from the targeted market in the most efficient way. 


\section{Populärvetenskaplig sammanfattning}

Ett ramverk har tagits fram som kan användas när ett byggföretag vill utveckla ett nytt eller förändra sitt befintliga produktionssystem. I dagsläget finns inga ramverk för produktionsstrategi anpassade till byggindustrin och målet med detta forskningsprojekt är att fylla den luckan.

Grundtanken i detta arbete är att det inte går att utveckla ett produktionssystem som är bra på allt. Vill ett företag exempelvis producera sina hus till lägsta möjliga kostnad innebär det med stor sannolikhet att huset måste standardiseras i relativt stor grad. Det finns alltså styrkor och svagheter inbyggda in olika produktionssystem. Ofta är det en avvägning mellan flexibilitet, i meningen att kunna möta kundens önskemål, å ena sidan och kostnad och tid å andra sidan. Produktionssystemet ska utformas med utgångspunkt i vad som är viktigt för det marknadssegment de producerande företagen vänder sig till.

För att kunna producera flerbostadshus på ett effektivt sätt måste först en analys över marknaden göras. Vilket kundsegment företaget vill nå samt hur konkurrenssituationen ser ut för det segmentet är frågor som måste utredas. När en tydlig bild över kunder och konkurrenter tagits fram kan produktionssystemet utformas så att det är anpassat till att möta de krav och önskemål som kunderna efterfrågar. Lyckas detta kan kundernas behov tillgodoses, vilket ger nöjda kunder samtidigt som verksamheten blir effektiv och lönsam. Detta kan låta enkelt, men i praktiken kan det vara svårt att se kopplingen mellan olika konkurrensfaktorer (kostnad, kvalitet, tid, flexibilitet etc.) och de olika beslut som måste tas inom olika områden (personal, organisationsstruktur, materialförsörjning, val av produktionsprocess etc.) för att utforma sitt produktionssystem så det möter kundkraven på ett effektivt sätt. Tanken är att ramverket som presenteras i denna avhandling ska hjälpa till med detta.

Så här långt har fokus legat på hur utforminingen av produktionssystemet och produkten påverkar förmågan att prestera inom olika konkurrensområden. För att se den kopplingen har en klassificeringsmatris tagits fram som visar relationen mellan ett produktionssystems industrialiseringsgrad och graden av produktstandardisering. För att kunna koppla denna så kallade produkt-process matris till konkurrensförmåga har även ett system för mätning av kvalitet, leverans (hastighet och tillförlitlighet), produktionskostnad (nivå och tillförlitlighet) och flexibilitet (volym, mix och expansion) tagits fram.

Klassificeringsmatrisen och de föreslagna mätetalen är ett första steg i framtagandet av ett produktionsstrategiramverk anpassat till byggbranschen och produktion av flerfamiljshus. 


\section{Foreword}

"An expert is a person that knows more and more, about less and less, until that person knows absolutely everything about nothing"

So does the process of getting a $\mathrm{PhD}$ make you an expert? I don't know, but what I do know is that being a $\mathrm{PhD}$ student is a challenging, exciting and fun occupation. However, for the life as a PhD-student to be fun and exciting you are dependent on a number of persons in your surroundings. I want to dedicate the next few lines to those persons.

The first person that I want to thank is my supervisor Professor Martin Rudberg, I could not ask for a better supervisor and I am truly grateful for the time and devotion that you put in to help and support me in the research process.

I also want to thank my colleagues in the construction logistics group, Micael Thunberg, Martin Heljedal, Fredrik Person, Andreas Ekeskär and Anna Fredriksson for contributing to the quality of this thesis. I also want to thank a former member of the group, Magnus Lindskog, for great support and high quality feedback especially on paper 2 and paper 3 .

Thirdly I want to thank my colleagues at the division of Communications- and Transport Systems. I want to send special thanks to Ellen Grumert and Åsa Weinholt for not only being great colleagues but also dear friends, you guys are awesome!

Finally I want to send a big portion of love to my family, at the moment located in Göteborg, Norrköping, Södertälje and Örnsköldsvik. I want to thank my wife Therese, without your love and support I'm sure this would have been neither fun nor exciting. I love you and Arvid so much!

Norrköping, April 2014

Henric Jonsson 


\section{Acknowledgement}

There are a number of persons that have contributed to this research that I also want to mention. I am very grateful to Jesper Strandberg, Ola Dietrichson, Helena Lidelöw, Ola Magnusson, Mikael Thorgren, Lars Eriksson, Roger Pettersson, Malin Nordgren, Mats Öberg, and Anton Lundholm. Thank you all for great discussions and input to the research project. I also want to thank Per Olsson and Andritz in Örnsköldsvik for providing a workspace at their office. The research has been financed by The Lars Erik Lundberg Foundation for Research and Education. 


\section{Thesis Outline}

This thesis is of a compilation character (thesis by publication) comprising three articles; one published in the scientific journal Construction Management \& Economics, one is under review for publication in the ISI-classified journal, Journal of Construction Engineering and Management, and one working paper. The thesis is titled: Towards a framework for production strategy in construction and it consists of two parts. The first part describes the background to the research and motivates why this research is important, presents the purpose and the research questions, clarifies the theoretical frame of reference consisting of three main areas, production strategy theory, off-site production in the construction industry and performance measurement. Finally, part one of the thesis also presents and describes the production strategy framework developed in this research, the research questions are answered, conclusions are presented and some ideas for further research are suggested. The second part of the thesis includes the three papers that the research builds' upon, which are listed below.

\section{Paper 1}

Jonsson, H. and Rudberg, M. (2014a). "Classification of production systems for industrialized building: a production strategy perspective". Construction management and Economics, 32(1-2), 53-69

\section{Paper 2}

Jonsson, H. and Rudberg, M. (2014b). “A production system classification matrix: matching product standardization and production system design”. Under review for publication in Journal of Construction Engineering and Management.

\section{Paper 3}

Jonsson, H. and Rudberg, M. (2014c). "Performance measurement for production systems in construction". Working Paper 
"I'm a luck man, to count on both hands the ones I love"

Eddie Vedder (2009) 


\section{Table of contents}

1. Introduction

1.1 Background 1

1.2 Scope of the research 3

1.3 Outline 5

2. Theoretical frame of reference

$\begin{array}{ll}2.1 \text { Production strategy } & 7\end{array}$

2.1.1 Decision categories 8

$\begin{array}{ll}2.1 .2 \text { Competitive priorities } & 13\end{array}$

$\begin{array}{ll}2.2 \text { Production strategy in construction } & 17\end{array}$

$\begin{array}{ll}\text { 2.2.1 Process choice for production of multifamily residences } & 17\end{array}$

$\begin{array}{ll}\text { 2.2.2 Competitive priorities in construction } & 19\end{array}$

2.3 Performance measurement production systems in construction 21

$\begin{array}{ll}\text { 2.3.1 The balanced scorecard } & 23\end{array}$

2.3.2 Quality based excellence models 23

2.3.3 Key performance indicators (KPI) 24

2.3.4 Summary performance measurement 29

3. Research design 31

3.1 The research process 31

3.1.1 Publication strategy 33

3.1.2 Author's Statement $\quad 34$

3.2 Choice of method 35

3.2.1 Case study 35

3.3 Judging the quality of the research

4. Summary of papers $\quad 39$

4.1 Summary of paper $1 \quad 39$

4.2 Summary of paper 2

4.3 Summary of paper $3 \quad 42$

5. A framework for production strategy in construction 47 
5.1 Research questions $\quad 47$

5.2 Content of the production strategy framework for construction 48

5.3 Process of the production strategy framework for construction 50

5.4 Case analysis using the suggested framework $\quad 51$

5.4.1 Example 1: Evaluating two different production systems 51

5.4.2 Example 2: Redesigning a production system 52

6. Contribution and further research 55

6.1 Purpose and contribution $\quad 55$

6.1.1 Scientific contribution $\quad 55$

6.1.2 Contribution to the construction industry 56

6.2 Further research 56

$\begin{array}{lr}\text { References } & 59\end{array}$ 


\section{Introduction}

This chapter describes the background of this research project. The underlying problems are described to motivate the research and the purpose of the research is presented.

\subsection{Background}

The problem with low productivity increase in the construction industry is highlighted in many studies from different countries (Larsson et al., 2013). Egan (1998) and Teicholz et al. (2001) gives examples from the UK and the US construction industry respectively. In Sweden the need to improve productivity and client satisfaction in the construction industry has promoted a number of government investigations (see e.g. SOU, 2002:115, Statskontoret, 2009). More recent reports indicate that low productivity still is a problem in the Swedish construction sector (Josephson, 2013). However, in Josephson (2013) it is highlighted that even though there are obvious productivity losses in all parts of the building process there are examples of projects that deliver good productivity. This indicates that there are large gaps between the levels of productivity between different projects. Lind and Song (2012) takes the debate further and state that there are too many errors in the way productivity is measured to be able to say whether the productivity development in the construction industry is as slow as many studies indicate. However, other studies have shown that large amounts of time, material and other resources are wasted in traditional on-site construction projects (Larsson et al., 2013). This type of waste has a negative effect on productivity.

Means have been issued to resolve these problems, both from industry and academia, but few of them have been successful in the long run (Nadim and Goulding, 2011). One suggested way of improving the construction industry is to move value adding activities off-site, to a more industrial environment (Eriksson et al., 2013, Gibb and Isack, 2003). This way of producing buildings is termed different in different literature. The terms in use can be grouped, by affix, under four categories: off-site (e.g. off-site construction/fabrication/manufacturing), pre- (e.g. assembly/fabrication/work), modern (e.g. modern methods of construction), and building (e.g. industrialized building, system building, non-traditional building) (Pan et al., 2012b). In this thesis the different terms are used interchangeably but in most parts the term off-site production is used for consistency.

Off-site production has evolved over time and the first formative movement identified is prefabrication, followed by building in sub-assemblies. Prefabrication and built in subassemblies were further evolved to modularization and more open systems where the use 
of integrated interfaces make it possible to combine standard components in order to enable a wide array of choice for the customer (Ågren and Wing, 2013). The different stages that have evolved over time describe different degrees of off-site production which can be found in production systems in use today (see e.g. Barlow et al., 2003, Pan et al., 2007, Thuesen and Hvam, 2011)

Compared to traditional on-site production, off-site production has been said to have many advantages (Kadir et al., 2006, Meiling et al., 2012) such as: higher productivity, lower production cost, higher quality and better on-time delivery, to name a few. The trade-off when increasing the degree of off-site production is reduced product and process flexibility. The trade-off between productivity and flexibility indicates that different production systems perform well in different areas of competition, and could be an explanation to the big difference in productivity between different construction projects. This is in line with the reasoning in traditional production strategy literature (see e.g. Hayes and Wheelwright, 1984, Miltenburg, 2005) and from a construction industry perspective it is interesting to investigate this further, i.e. investigate how the characteristics of a production system affects the ability to deliver manufacturing outputs.

To do this, different production systems must be categorized so that similarities and differences in characteristics are exposed. The design of the production system can then be linked to performance. This link between production system design and performance is typically omitted in previous construction literature and the fact that different production systems can be efficient in different areas of competition, depending on the nature of the requirements, is not highlighted in the frameworks developed for classifying production systems in construction (Jonsson and Rudberg, 2014a). The link between market strategy and the manufacturing task is thereby neglected, leading to that production systems might not be designed to provide competitiveness in the targeted market. A production strategy framework for the construction industry would give construction companies a tool to work with production strategy in a structured way.

For the manufacturing industry, these kinds of structured production strategy frameworks have been developed over the years (see e.g. Hayes and Wheelwright, 1979, Hill, 2000, Miltenburg, 2005), tailored to facilitate the design of the production system so that it serves the market in the most efficient way (i.e. link the market strategy to the production task). These frameworks have been shown useful for manufacturing firms when designing new production systems, or when improving already existing ones. To my knowledge there are no corresponding frameworks developed for the construction industry.

The purpose of this research is to develop such a production strategy framework for the construction industry, and more specifically for the production of multifamily residences. By linking the design of different production systems to the ability of the production systems to perform, the link between the market and the production function is visualised. As mentioned before such a framework should be useful when designing a new, or improving an already existing, production system so that it will meet the demands from the targeted market in an efficient way. 
When it comes to layout, the typical type of production system used in the construction industry is a project based production system. The conditions and prerequisites are more or less unique for each project, and a production system designed for one context might not be the best choice for another. In traditional production strategy literature the project based production systems are often left out of the scope due to the unique characteristics of those one-off products (see e.g. Miltenburg, 2005). However, for the construction industry that typically use project based production systems, it would be interesting to investigate the different variations of project based production systems, e.g. production systems with different degrees of off-site production, that exist. This can be done by classifying different production systems for construction based on their product and process characteristics in a matrix corresponding to the product-process matrix (Hayes and Wheelwright, 1979). This classification of construction production systems can then be linked to different manufacturing outputs (e.g. production cost, delivery and quality) to evaluate the different production systems ability to meet demands from the market, similar to the framework presented in Miltenburg (2005).

In this thesis focus is on two parts. The first part is a classification part where different production systems can be positioned based on the product and process characteristics. To develop this part the following research question is addressed:

RQ1. What dimensions can be useful, from a production strategy perspective, when classifying different production systems for the production of multifamily residences?

The second part is related to performance evaluation of production systems. In this part a performance measurement system is defined to measure the ability of different production systems to perform in different areas of competition. To develop a system for performance measurement system the following two research questions are addressed:

RQ2. What manufacturing outputs/competitive priorities have to be taken into consideration when evaluating different production systems for production of multifamily residences?

RQ3. How should the ability of a production system to deliver manufacturing outputs be measured?

The two parts developed and presented in this thesis are, when related to one another, called a framework. However, it is not a complete production strategy framework for construction, just the first important step in the process of developing one. That is why the thesis is named "Towards a framework for production strategy in construction".

\subsection{Scope of the research}

In this research the construction industry is in focus. More specifically the scope of this research is to analyse production systems for production of multifamily residences. A multifamily residence is a building designed to house several families in separate housing units. In 2012 multifamily residences represented about $75 \%$ of the total number of residences produced in Sweden (Sveriges Byggindustrier, 2013). The reason for focusing 
on the production of multifamily residences is related to aspects such as, an increasing demand for both rental apartments and condominiums (Boverket, 2012), increasing production costs and decreased productivity (Larsson et al., 2013), and the fact that the relative amount of money a family spends on their accommodation increases (Lind and Song, 2012). Smaller constructions such as single-family residences, larger constructions (e.g. big arenas) and civil engineering projects (e.g. roads, railway, bridges) are not taken into consideration in this research.

The unit of analysis is production systems that produce whole buildings. In this research the production system is defined as the parts of the firm involved in producing the building, this is visualized for on-site and off-site production respectively in Figure 1.

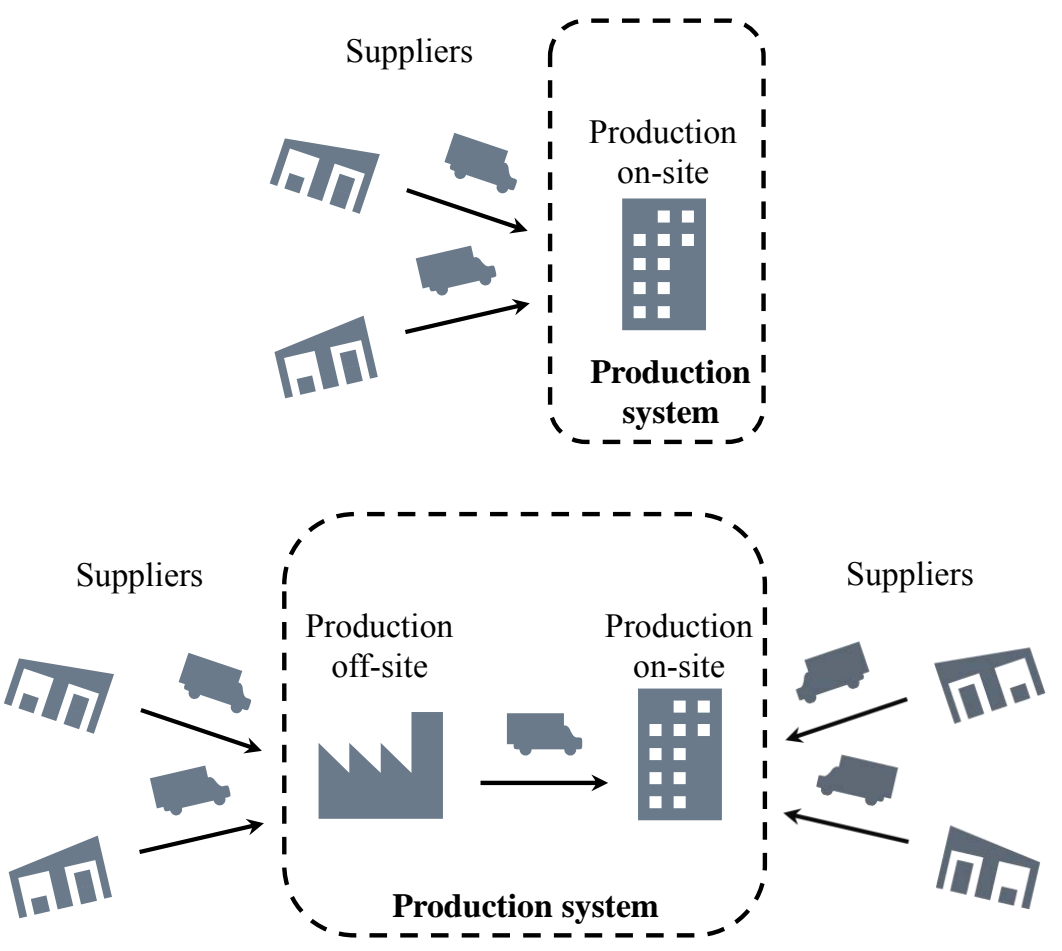

Figure 1 Visualisation of the production system for traditional on-site production and offsite production respectively

For the empirically grounded part of this research case studies were chosen as the primary research method. The companies used in this research are all firms operating in Sweden. The main focus of this research is on off-site production. Traditional on-site production is considered as a baseline benchmark, but is treated as one concept when in reality you can produce buildings on-site in different ways and adapting different strategies within the concept depending on the prerequisites. The focus on off-site production is also reflected in the case companies that all use production systems that in some sense are different from traditional on-site production. 


\subsection{Outline}

To address the purpose and the three research questions the research is divided into three phases. In the first and third phase focus is on developing theoretical constructs and refining theoretical constructs respectively, based on existing literature and conceptual modelling. The literature used in these phases is presented in chapter 2 of this thesis. In the second phase empirical data is used to test the theoretical constructs developed in the first phase. The process of developing, testing and further refining the theoretical constructs is described in chapter 3. In this part of the thesis the choice of method is described and motivated to strengthen the trustworthiness of the research results and the conclusions. In chapter 4 the three papers, that are included in this thesis, are summarised. In chapter 5 the actual production strategy framework for production of multifamily residences is presented. When describing the framework the main focus is on the content of the framework. However, the production strategy process is also described using the case companies in an attempt to explain how the framework can be used both in academia and in practice. In the last part, chapter 6, the main conclusions of the research is presented together with directions for further research. 


\section{Theoretical frame of reference}

This section describes the theories that the research in this thesis builds upon. The theoretical frame of reference consists of three main areas, production strategy, off-site production in the construction industry and performance measurement.

\subsection{Production strategy}

To be able to manage the different challenges that the production function faces a production strategy has to exist. A production strategy helps a company to make operational and strategic decisions that follow a logical pattern. When no strategy exists the decisions will be arbitrary and unpredictable (Miltenburg, 2005).

According to the seminal paper by Skinner (1969), production strategy (also termed manufacturing strategy) refers to exploiting certain properties of the manufacturing function as a competitive weapon. Since that paper, production strategy has been defined and interpreted by various researchers. In a comprehensive literature review on manufacturing strategy Dangayach and Deshmukh (2001) compiled definitions of production strategy formulated by various authors. There are some variations in the definitions but all in all they are quite similar. As an example Cox and Blackstone (1998) defines production strategy as a collective pattern of decisions that acts upon the formulation and deployment of manufacturing resources. To be most effective, the production strategy should act in support of the overall strategic directions of the business and provide for competitive advantage (Dangayach and Deshmukh, 2001). When reviewing the different definitions of production strategy it is obvious that the link between the overall business and market strategy and the production function of the firm is central.

Another aspect that has to be taken into consideration is the distinction between production strategy content and production strategy process. This distinction was highlighted in Leong et al. (1990) when they made a comparison between business strategy research and production strategy research. In the former the distinction between content and process had been noted since long whilst in production strategy literature the process and content issues had been tightly intertwined. The content part of production strategy focuses on the specific decisions that form the production system whereas the process addresses how such decisions are implemented and used in an organizational setting (Fahey and Christensen, 1986). This is an important distinction to acknowledge since a discussion about the strategy process is not relevant until the strategy content is well defined (Rudberg, 2002). In a construction industry context the production strategy 
content is not that well researched, hence in this research the main focus is on production strategy content.

Traditionally the content of production strategy is built around two groups; decision categories that are of long term importance in the manufacturing function and competitive priorities that are based on the market strategy of the firm (Leong et al., 1990), this is visualised in Figure 2. Another term that is used for competitive priorities is manufacturing outputs. The two terms describe the same thing but from different perspectives. The difference is that the term manufacturing outputs is used when describing what the production function of the firm is able to deliver. The term competitive priorities is used when describing the market strategy of the firm in terms of what the targeted customers think is important. The following sentence including both terms clarifies the difference further, "from a production strategy perspective it is important that the production function of the firm delivers manufacturing outputs that support the competitive priorities of the business". Both terms are used in this thesis.

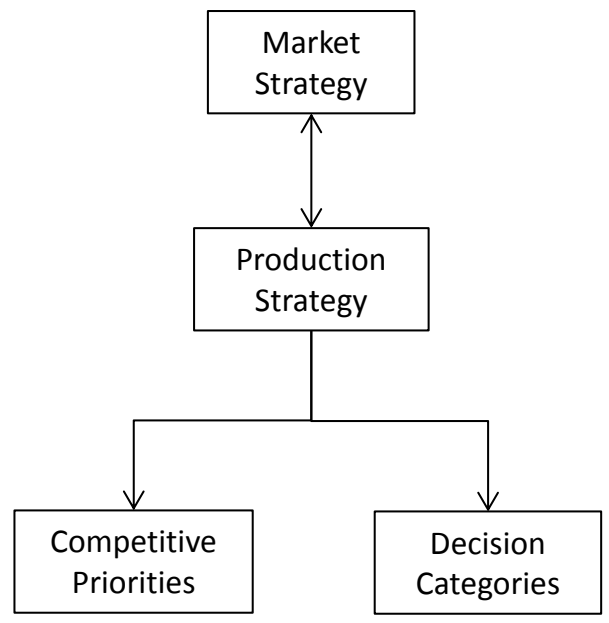

Figure 2 Content model of production strategy (Leong et al., 1990)

Decision Categories and Competitive priorities are vital terms in this research and described more in detail in the following.

\subsubsection{Decision categories}

Decision categories are areas in which a company must take decisions that are of long term importance for the production function to be able to meet the market strategy of the firm (Leong et al., 1990). The decision categories can be categorized as structural or infrastructural. This distinction between structural decisions and infrastructural decisions was introduced by Hayes and Wheelwright (1984). The structural decisions are decisions that have long-term impact on the production function, are difficult to reverse and undo when they are implemented and typically requires substantial capital investments. The infrastructural decisions affect the people and systems that make the production function work. 
The sets of decision categories differ somewhat between authors, but there is an essential agreement on the areas that really matters for the production strategy (Leong et al., 1990). Leong et al. (1990) made a comparison between decision categories and the result form that review is presented in Table 1. The decision categories presented in Miltenburg (2005) and Slack and Lewis (2011) are also included as a complement to the sources published prior to the review performed by Leong et al. (1990). Worth mentioning is that Skinner (1969) includes the decision categories facilities, technology, capacity and vertical integration in the decision category plant and equipment. Skinner also includes quality in the decision category production planning and control. 


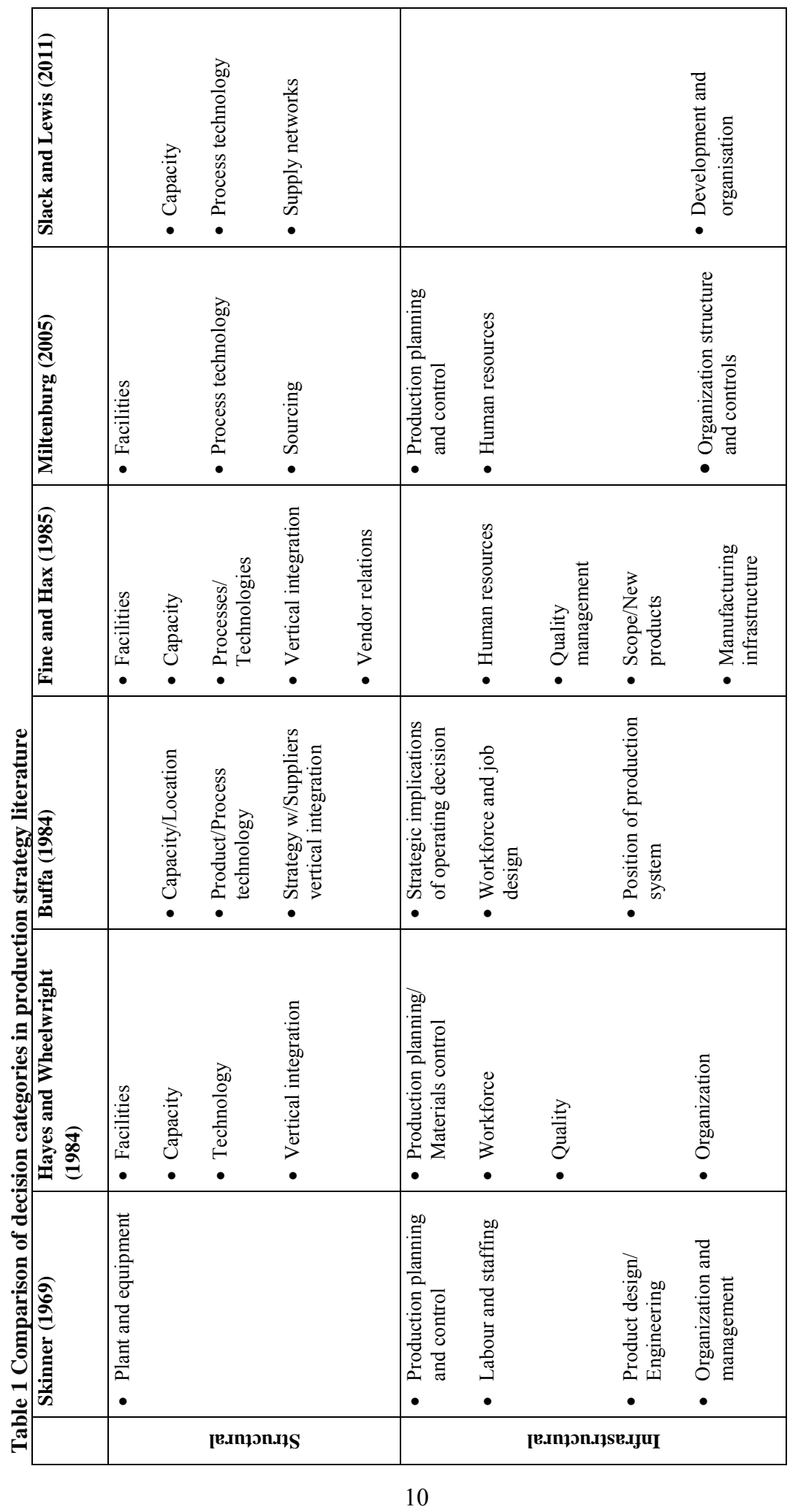


In this research focus is on the decision category typically named technology or product/process technology. Technology includes decisions regarding the technology that is incorporated in specific pieces of manufacturing equipment, the degree of automation in the production and material-handling process and the connections between different production stages (Hayes and Wheelwright, 1984). According to Hill and Hill (2009) the most significant decisions a manufacturing company has to make is related to the decision category product and process technology and concern customers, products and the process by which to make them. When choosing the appropriate way to produce its products, a company must choose between alternative production approaches and use the type of production system that best deliver manufacturing outputs that support the competitive priorities of the company. Factors that have to be taken into consideration are product characteristics, e.g. complexity and volumes, type of manufacturing process and the business implications of the product and process decisions. These factors are referred to as the process choice (Hill and Hill, 2009), i.e. choosing a production system that supports the competitive priorities of the firm (Rudberg, 2004) and constitute the base in many production strategy frameworks developed for the manufacturing industry (see e.g. Hayes and Wheelwright, 1984, Hill and Hill, 2009, Miltenburg, 2005).

To categorize different production systems Hayes and Wheelwright (1979) introduced the product-process matrix. This matrix is used in various production strategy frameworks (see e.g. Hayes and Wheelwright, 1984, Hill and Hill, 2009, Miltenburg, 2005) to visualise the characteristics of different production systems and facilitate the process choice. Separating the concept of the product life cycle and the process life cycle facilitates the understanding of the different strategic options, both marketing and manufacturing, available to the company. By using the dimension product life cycle, in terms of production volume and standardisation (low/low to high/high) on the $\mathrm{x}$-axis, and process life cycle (job shop, batch flow, line flow, and continuous flow) on the y-axis, correlations between the product structure and the process structure are visualised (Figure 3). 


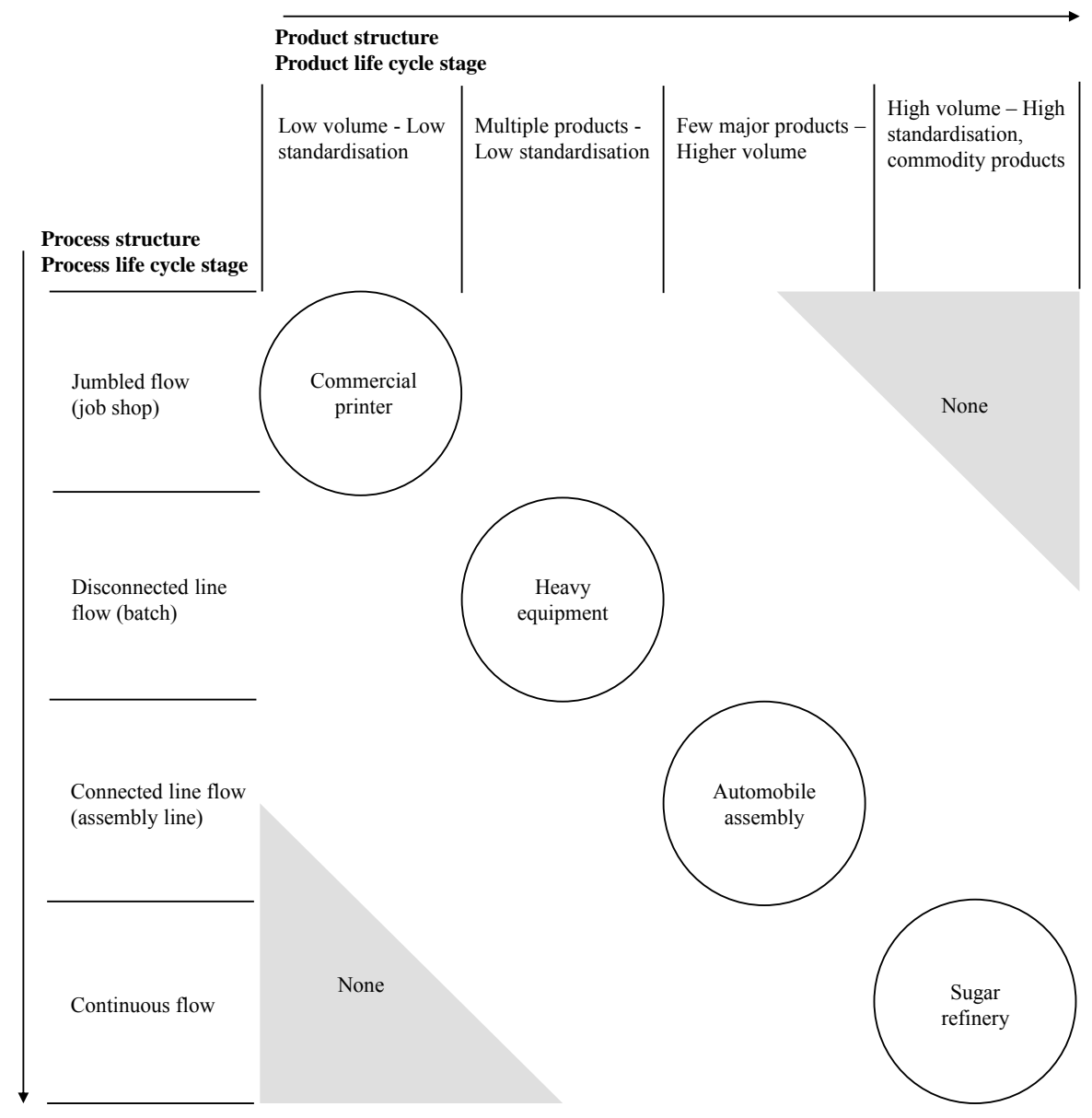

Figure 3 Product-process matrix (Hayes and Wheelwright, 1979)

To explain and clarify how the product and process are related to each other Hayes and Wheelwright (1979) give examples of typical products mapped in the matrix (Figure 3). The example commercial printer might not be a good example today, but in 1979 it was a good example of a product produced in low volumes and with a low degree of standardization. A better example from today is a Formula 1 racing car. The point is that different process structures are suitable for different product structures. If the market demands a customised product, the production system must be flexible, and in such cases a job shop structure is preferable to a continuous flow or assembly line structure. If the market demands a standardised product, in high volumes and produced at a low cost, a continuous flow structure of the production system is the better choice. This way of matching the characteristics of the product with the characteristics of the process suggests that a production system should ideally be positioned along the diagonal in the productprocess matrix. A position too far away from the diagonal should typically be avoided 
since there, in theory, is a risk that a production system designed that way will be outperformed by competitors better positioned in the matrix.

\subsubsection{Competitive priorities}

Competitive priorities are a set of goals for manufacturing (Leong et al., 1990) to connect the market strategy with the production task, i.e. deciding in what areas of competition the firm wants to compete. The production strategy literature agrees on some of the competitive priorities while others are more author-specific. Table 2 provides an overview of competitive priorities that different authors consider important in a production strategy context. The competitive priorities quality, delivery (speed and dependability), cost, and flexibility are mentioned (in one form or the other) by all authors.

Table 2 Summary of competitive priorities (Jonsson and Rudberg, 2014c)

\begin{tabular}{|l|l|l|l|}
\hline Miltenburg (2005) & Hill and Hill (2009) & Slack and Lewis (2011) & Leong et al. (1990) \\
\hline Quality & Quality conformance & Quality & Quality \\
\hline Delivery & Delivery speed & Speed & Delivery \\
\hline Cost & Delivery reliability & Dependability & \\
\hline Flexibility & Price & Cost & Cost \\
\hline & Product range & Flexibility & Flexibility \\
\hline & $\begin{array}{l}\text { Demand increase } \\
\text { response }\end{array}$ & & \\
\hline & Colour range & & \\
\hline Innovativeness & Design & & Innovativeness \\
\hline Performance & & & \\
\hline & & & \\
\hline & Brand name* & & \\
\hline & Technical support* & & \\
\hline
\end{tabular}

*Not production related.

The majority of production strategy research adopts trade-off reasoning when it comes to competitive priorities, meaning that focusing on improving the ability to deliver one manufacturing output will be at the expense of others (Hayes and Wheelwright, 1984, Hill and Hill, 2009, Miltenburg, 2005). Manufacturing outputs that have been found to be of contesting nature are for example quality and cost, cost and delivery lead times, and flexibility and cost efficiency (Hallgren et al., 2011). Trade-off reasoning thereby suggests that a certain production system cannot outperform its competitors in all areas of competition, and it is therefore important to design the production system so that it supports the market strategy of the firm. To highlight the fact that a firm and its production system cannot provide competitiveness along all competitive priorities, Hill and Hill (2009) introduces the terms order winner and order qualifier. To win orders a firm has to perform in parity, or better, than its competitors in one or more areas of competition. This will be done at the sacrifice of other areas, which still, however, has to be at an acceptable level (order qualifying level), otherwise the customer will not consider the firm at all. 
The concept of cumulative capabilities (Ferdows and Meyer, 1990) is an alternative perspective when discussing the relation between competitive priorities. It suggests that improvements of one competitive priority will facilitate improvements in other areas of competition. The sand cone model (Figure 4) suggests that even though the ultimate goal for the manufacturing function is to make the process cost efficient, first improvements to enhance quality must be made, then attention should be paid to improve dependability (on time delivery), then flexibility (speed) and not until a certain level within these areas has been reached direct attention can be paid to cost efficiency (Ferdows and Meyer, 1990).

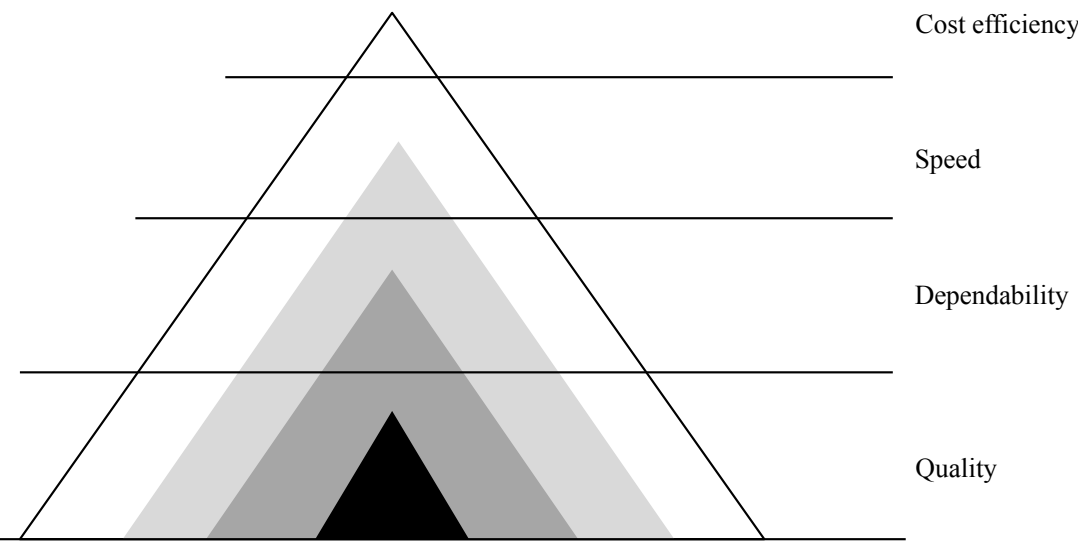

Figure 4 The sand cone model (Ferdows and Meyer, 1990)

At first, trade-off and cumulative capabilities seem to be competing rivals but Schmenner and Swink (1998) argue that the two are rather complements than rivals. This can be explained by that trade-off and cumulative capabilities are different in the sense that the trade-off is reflected in comparisons across plants at a given point in time, whereas cumulative capabilities is reflected in improvements within individual plants over time (Schmenner and Swink, 1998). From a production strategy perspective both comparison across plants and improvements over time are important aspects. However, when developing a production strategy framework a comparison between different production systems is to be made. The purpose of such a framework is to visualise different production systems relative strengths and weaknesses. In that context trade-off reasoning is argued to be valid.

\subsubsection{Production strategy frameworks}

Production strategy is complex and to design a production system that meets the demands from the market in the most efficient way many factors have to be taken into consideration. Different methods and frameworks for doing this in a structured and efficient way have been described in the literature (see e.g. Hayes and Wheelwright, 1984, Hill and Hill, 2009, Miltenburg, 2005). 
To put the content and process of the production strategy theory in a context Miltelburg's (2005) framework is described. Unless something else is stated, the information used in the description is from Miltenburg (2005).

The content of Miltenburg's framework contains the two groups which most production strategy theory builds upon, decision categories and manufacturing outputs. The decision categories are presented on the left hand side of the framework (Figure 5). The decision categories (termed manufacturing levers) included are: process choice represented by the PV-LF matrix which is an adoption of the product-process matrix (Hayes and Wheelwright, 1979), human resources, organisation structure \& controls, production planning \& control, sourcing, process technology and facilities. The manufacturing outputs are represented on the right hand side of the framework and the ones included are: delivery, cost, quality, performance, flexibility, and innovativeness.

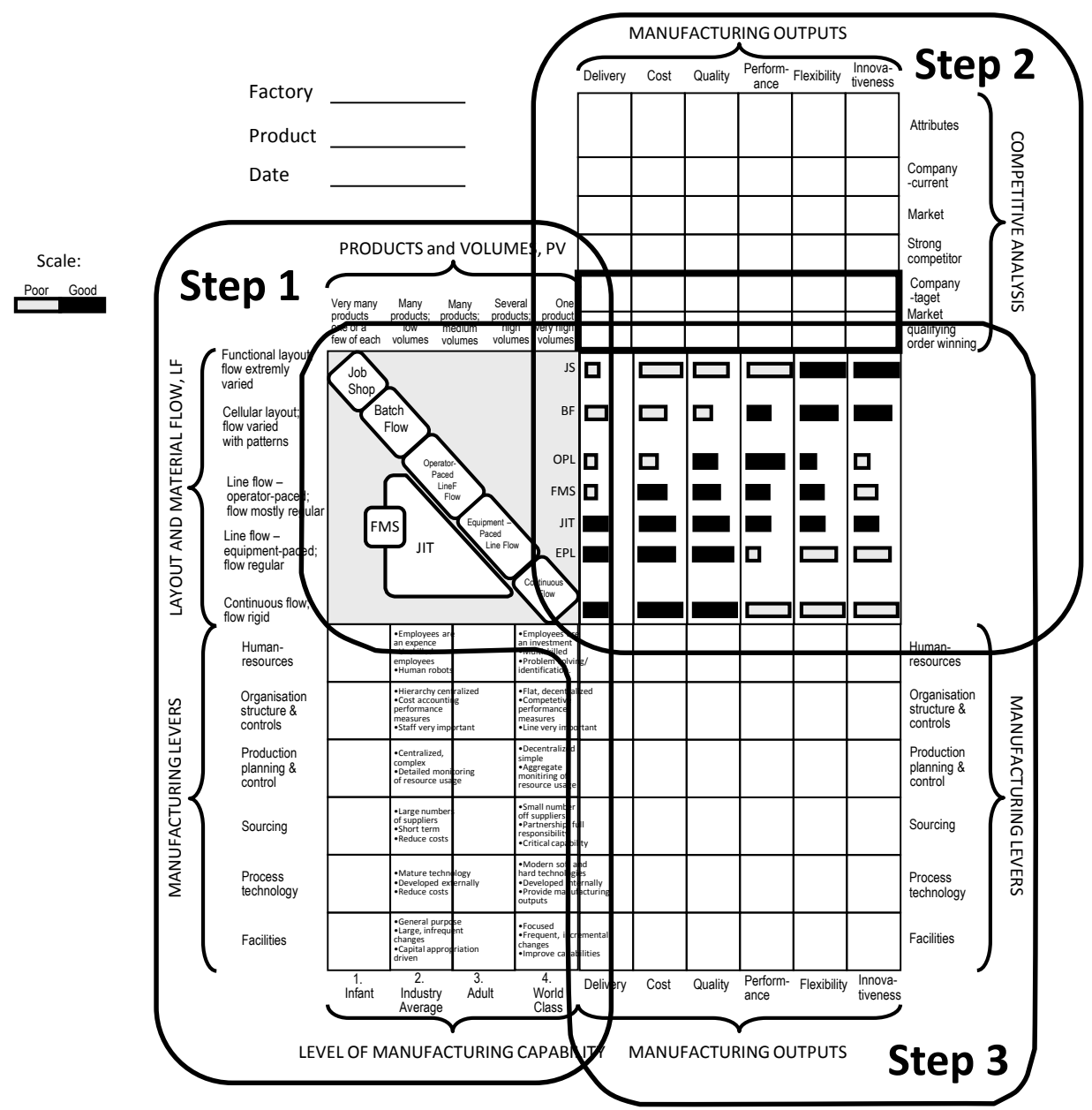

Figure 5 Miltenburg's (2005) framework for production strategy 
The mid-section of the framework visualizes the link between the production systems and the market. The relative ability of each generic production system to deliver manufacturing outputs is valued on a scale ranging from poor (represented by a long grey bar) to good (represented by a long black bar). This judgement of the production systems is done under the prerequisite that the production systems are managed well.

The production strategy framework can be used in a number of ways:

- Analyse a factory

- Generate and evaluate alternate strategies

- Analyse competitors' strategies

- Develop a production strategy for a factory

- Help develop a manufacturing strategy for each factory in a manufacturing network

In the following the process of developing a production strategy for a factory is described. This process of developing a production strategy for a factory follows three steps. Which part of the production strategy framework that is used in each step is visualised in Figure 5 .

In the first step the current status of the factory is defined. The production systems position on the PV-LF matrix is determined. The current level of capability for each decision category is also assessed using the "manufacturing levers" part of Figure 5. This step is not relevant if a production strategy is developed for a new factory.

In the second step the future status of the factory is defined. This step includes a competitive analysis to determine the qualifying and order winning outputs that the production system must provide. By using the mid-section of Figure 5 the row of black and grey bars that best matches the required market qualifying and order winning outputs can be located, hence also determine what type of production systems that best meets the demands from the targeted market. This step is relevant both when designing a new production system and when changing an existing production system.

In the third and final step it is decided how to get from the current status of the factory to the future status, i.e. taking the factory from where it is, to where it should be. If the first and second step shows that the production system currently in use is the right type of production to best deliver the required manufacturing outputs the production system can be improved by adjusting the manufacturing levers, but without changing the production system. If there is a mismatch between the production system in use and the competitive analysis performed in step two the manufacturing levers must be adjusted so that the current production system is changed to the desired production system. In case a new production system is developed, this third step concerns deciding how to design the production system so that it meets the demands from the market in the best way. 


\subsection{Production strategy in construction}

The basic theories of production strategy for the construction industry are no different than for traditional manufacturing. The production system must be designed so that it delivers manufacturing outputs at a level that support the competitive priorities of the firm. As mentioned in the introduction of this thesis the typical approach when producing multifamily residences is a project based approach but that the characteristics of each project are more or less unique. Related to the process choice (Hill and Hill, 2009) it is also important in a construction industry context to choose an appropriate production system that can meet the demands from the targeted market in an efficient way.

\subsubsection{Process choice for production of multifamily residences}

Just as there are different types of production systems for traditional manufacturing there are different ways of producing multifamily residences. The main focus in this research is on off-site production but on-site production is also taken into consideration as one type of production system. Kamar et al. (2011) made a comparison between different classifications of production systems in construction and from that review they derived the following seven generic production systems:

1. Frame system

2. Panellised system

3. On-site fabrication

4. Sub-assembly and components

5. Block work system

6. Hybrid system

7. Volumetric and modular system

In the list of different classifications of industrialized building systems (Kamar et al., 2011) most classifications are based on how much of the building is produced off-site. This is also highlighted in a study by Azman et al. (2010) in which examples of how offsite production systems are categorized in different countries are given (Table 3 ). 
Table 3 Categorization of production systems in different countries (Azman et al., 2010)

\begin{tabular}{|c|c|}
\hline Country & Categorization of production system \\
\hline US & $\begin{array}{l}\text { - Off-site pre-assembly } \\
\text { - Hybrid system } \\
\text { - Panellised system } \\
\text { - Modular building }\end{array}$ \\
\hline UK & $\begin{array}{l}\text { - } \quad \text { Component manufacture \& sub-assembly } \\
\text { - Non-volumetric pre-assembly } \\
\text { - Volumetric pre-assembly } \\
\text { - } \quad \text { Modular building }\end{array}$ \\
\hline Australia & $\begin{array}{l}\text { - Non-volumetric pre-assembly } \\
\text { - Volumetric pre-assembly } \\
\text { - Modular building }\end{array}$ \\
\hline Malaysia & $\begin{array}{l}\text { - Pre-cast concrete system } \\
\text { - Formworks system } \\
\text { - Steel framing systems } \\
\text { - Prefabricated timber framing systems } \\
\text { - Block work systems } \\
\text { - Innovative product systems }\end{array}$ \\
\hline
\end{tabular}

The categorization used in UK was defined in Gibb (2001) and represent four types of production systems with varying degrees of off-site production ranging from component manufacture and sub-assembly, which is the traditional way of producing buildings onsite, to modular building. One advantage of the production systems defined by Gibb (2001) compared to the classifications used in the US and Australia is that traditional onsite production is included and defined. Compared to the seven production systems defined by Kamar et al. (2011), where on-site is included, it can be argued that:

- On-site fabrication and sub-assembly and components correspond to component manufacture and sub-assembly

- Panelised system correspond to non-volumetric pre-assembly

- Block work system correspond to volumetric pre-assembly

- Volumetric and modular system correspond to modular building

The hybrid system is a combination of two or more of the production systems defined in Gibb (2001) and to include that systems as a generic production system is not considered necessary. Frame system describes prefabricated framing systems but since a structural framework is included in all types of buildings the framing systems are included in all four production systems defined by Gibb (2001). For the reasons given above it seems like the four production systems defined by Gibb (2001) gives a good representation of different production systems used for production of multifamily residences. 
The four types of production defined as follows:

Component manufacture and sub-assembly: Many components used in construction are actually sub-assemblies (e.g. door furniture or light fittings). This category includes all small scale sub-assemblies that would never be considered for on-site assembly in any developed country. (Gibb, 2001, p. 308)

Non-volumetric pre-assembly: These items are assembled in a factory, or at least prior to being placed in their final position. They may include several sub-assemblies and constitute a significant part of the building or structure. Examples include wall panels, structural sections and pipework assemblies. (Gibb, 2001, p. 309)

Volumetric pre-assembly: These items are also assembled in a factory. They differ from non-volumetric in that they enclose usable space and usually are installed on-site within an independent structural frame. Examples include toilet pods, plant room units, preassembled building services risers and modular lift shafts. (Gibb, 2001, p. 309)

Modular Building: These items are similar to volumetric units, but in this case the units themselves form the building, as well as enclosing useable space. They may be clad externally on-site with 'cosmetic' brickwork as a secondary operation. Examples include office blocks and motels and concrete multi-storey modular units used for residential blocks. (Gibb, 2001, p. 309)

To define different production systems based on the degree of off-site production is commonly used in the literature. The next step is to see how the degree of off-site production affects the production systems ability to deliver manufacturing outputs.

\subsubsection{Competitive priorities in construction}

A key to a successful production strategy is to design a production system that meets customer requirements in the most effective way. It is impossible to design a production system that outperforms all other production systems in all areas of competition. In traditional production strategy literature a set of competitive priorities are defined ( Table 2 ). To find out if the set of competitive priorities defined for traditional manufacturing are relevant in a construction industry context a review of literature describing drivers and barriers for increasing the degree of off-site production was performed. Table 4 summarizes the identified drivers and barriers for increasing the degree of off-site production. 
Table 4 Drivers and barriers for off-site production (Jonsson and Rudberg, 2014a)

\begin{tabular}{|c|c|c|c|c|c|c|c|c|c|c|c|c|c|}
\hline & & & & & & & & & & & & & \\
\hline & & 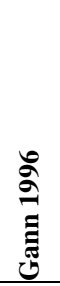 & 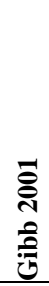 & 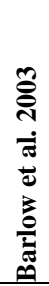 & 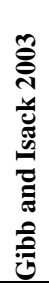 & 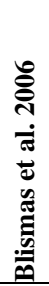 & 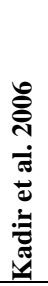 & 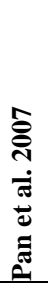 & 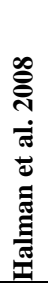 & 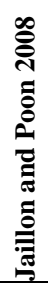 & 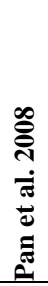 & 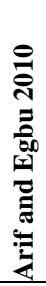 & 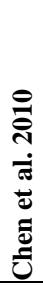 \\
\hline \multirow{12}{*}{ 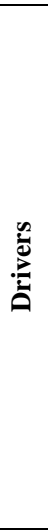 } & Quality & & $\bullet$ & $\bullet$ & $\bullet$ & $\bullet$ & & $\bullet$ & $\bullet$ & $\bullet$ & $\bullet$ & $\bullet$ & $\bullet$ \\
\hline & Time & & & & - & - & - & • & - & - & • & & - \\
\hline & Health and saftey & & $\bullet$ & & $\bullet$ & $\bullet$ & & $\bullet$ & & $\bullet$ & $\bullet$ & $\bullet$ & $\bullet$ \\
\hline & Cost & & $\bullet$ & & $\bullet$ & $\bullet$ & & $\bullet$ & $\bullet$ & $\bullet$ & $\bullet$ & & \\
\hline & Productivity & & $\bullet$ & $\bullet$ & $\bullet$ & $\bullet$ & $\bullet$ & $\bullet$ & & $\bullet$ & & & \\
\hline & Waste reduction & & $\bullet$ & & & & & & & $\bullet$ & & $\bullet$ & $\bullet$ \\
\hline & Management & $\bullet$ & $\bullet$ & • & & & & & & $\bullet$ & & & \\
\hline & Economies of scale & $\bullet$ & & & & & & & $\bullet$ & & & $\bullet$ & \\
\hline & $\begin{array}{l}\text { Human resource } \\
\text { management }\end{array}$ & & & & & $\bullet$ & & $\bullet$ & & & & - & \\
\hline & Technical possibilities & $\bullet$ & & $\bullet$ & & & & & & & & & \\
\hline & $\begin{array}{l}\text { Continuous } \\
\text { improvement }\end{array}$ & & $\bullet$ & & & & & & & & & & \\
\hline & More efficient logistics & & & & & & & & & & $\bullet$ & & \\
\hline \multirow{5}{*}{ 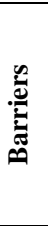 } & Flexibility & $\bullet$ & $\bullet$ & $\bullet$ & $\bullet$ & & & & $\bullet$ & $\bullet$ & & $\bullet$ & \\
\hline & Freeze design early & & $\bullet$ & & & $\bullet$ & & $\bullet$ & & & $\bullet$ & $\bullet$ & \\
\hline & Capital investments & & & & & $\bullet$ & & $\bullet$ & & $\bullet$ & $\bullet$ & $\bullet$ & \\
\hline & Capabilities & & & & $\bullet$ & & & $\bullet$ & & $\bullet$ & $\bullet$ & $\bullet$ & \\
\hline & $\begin{array}{l}\text { Need for high } \\
\text { production volumes }\end{array}$ & & & & - & & & $\bullet$ & & & $\bullet$ & & \\
\hline
\end{tabular}

As can be seen in Table 4, the most frequently mentioned drivers for using off-site production in construction are: improved quality, shorter and/or more predictable production time, health and safety issues, lower and/or more predicable production cost and higher productivity. Other drivers for using off-site production are that it facilitates waste reduction, increased possibilities for economies of scale, better project management and human resource management, technical possibilities, continuous improvement, and more efficient logistics. Turning to the barriers in Table 4, the most frequently mentioned ones are: reduced flexibility, the need to freeze design early, the level of capital investment, the different types of capabilities needed, and the need for high production volumes when investing in fixed assets for production.

The list of drivers and barriers for off-site production is longer than the list of competitive priorities listed in Table 2. However, the drivers and barriers can be clustered in a number of categories to link the drivers and barriers to the competitive priorities. The drivers and barriers are clustered under headlines based on traditional competitive priorities in Table 5. Many of the drivers and barriers can be related to competitive priorities in more than one way. The relations presented in Table 5 are considered direct relations. Other more indirect relations are not considered in Table 5, for example, 
continuous improvement is related to quality but not to cost even though the work with continuous improvements probably has an indirect impact on cost.

Table 5 Drivers and barriers related to competitive priorities

\begin{tabular}{|c|c|}
\hline Competitive priority & Drivers/barriers \\
\hline Quality & $\begin{array}{ll}\text { - } & \text { Quality } \\
\text { - } & \text { Project management } \\
\text { - } & \text { Technical possibilities } \\
\text { - } & \text { Continuous improvement } \\
\end{array}$ \\
\hline Delivery & $\begin{array}{ll}\text { - } & \text { Time } \\
\text { - } & \text { More efficient logistics } \\
\text { - } & \text { Productivity } \\
\text { - Technical possibilities } \\
\end{array}$ \\
\hline Cost & $\begin{array}{l}\text { - Health and safety } \\
\text { - } \text { Cost } \\
\text { - } \text { Productivity } \\
\text { - } \text { Waste reduction } \\
\text { - Economies of scale } \\
\text { - Human resource management } \\
\text { - Technical possibilities } \\
\text { - } \quad \text { More efficient logistics }\end{array}$ \\
\hline Flexibility & $\begin{array}{l}\text { - Flexibility } \\
\text { - Freeze the design early } \\
\text { - Capital investments } \\
\text { - The need for high production volumes }\end{array}$ \\
\hline
\end{tabular}

Two of the competitive priorities in Table 2, performance and innovativeness are included in Jonsson and Rudberg (2014a). The reason for including them was that the framework developed in that publication is to a large extent based on Miltenburg's (2005) framework for production strategy in which both performance and innovativeness are included. However, there is no obvious link between the drivers and barriers for off-site production and performance and innovativeness respectively so in Jonsson and Rudberg (2014b) and Jonsson and Rudberg (2014c) performance and innovativeness are left out of the scope and focus is on the competitive priorities quality, delivery, cost and flexibility.

Comparing the drivers and barriers in Table 4 with the typical manufacturing outputs Table 2, it seems that off-site production offers competitiveness in terms of delivery, cost and quality whilst it reduces the flexibility of the production system. This indicates that a higher degree of off-site production is not always the right answer to improve operations in construction, for instance exemplified by Kadir et al. (2006). Rather, a contingency approach must be followed when designing production systems, which includes knowledge about the ability of the chosen production system to perform (i.e. deliver manufacturing outputs) in different areas of competition.

\subsection{Performance measurement production systems in construction}

The focus on performance measurement has spread to many industries, including the construction industry (Bassioni et al., 2004). In the first quarter of the twentieth century 
methods for measuring financial performance were developed, DuPont for example introduced the return of investment measure and the pyramid of financial ratios (Bassioni et al., 2004). In 1950 dissatisfaction with financially based performance measures started to grow but did not start to build momentum until the late 1970s. Keegan et al. (1989) presented a performance matrix that classified the performance measures into cost and non-cost measures. The importance of measuring factors, other than financial, such as quality, time, process and flexibility was highlighted.

In construction various methods of measuring performance have been used. Robinson et al. (2005) investigated the utilization of performance measurement frameworks in leading U.K. construction firms and concluded that there were three methods that dominated the industry; the Balanced Scorecard, the European Foundation for Quality Management Excellence Model (EFQM Excellence Model) and the use of Key Performance Indicator (KPI) related systems.

When investigating potential systems for performance measurement in the construction industry used in a production strategy context it is important to make a distinction between performance management and performance measurement (Kagioglou et al., 2001). The performance management system is the process by which the company manages its performance. It is a process where feedback is provided from various levels in the organisation in order to manage the overall performance of the system. In a performance management system the strategy and policy of the organisation is in focus and deployed to all business processes, activities and personnel in the organisation. A performance measurement system is an information system and it constitutes the core process in the performance management system and provides the feedback that enables appropriate management decisions (Bititci et al., 1997). The content of a performance management system and the position of the performance measurement system is visualised in Figure 6.

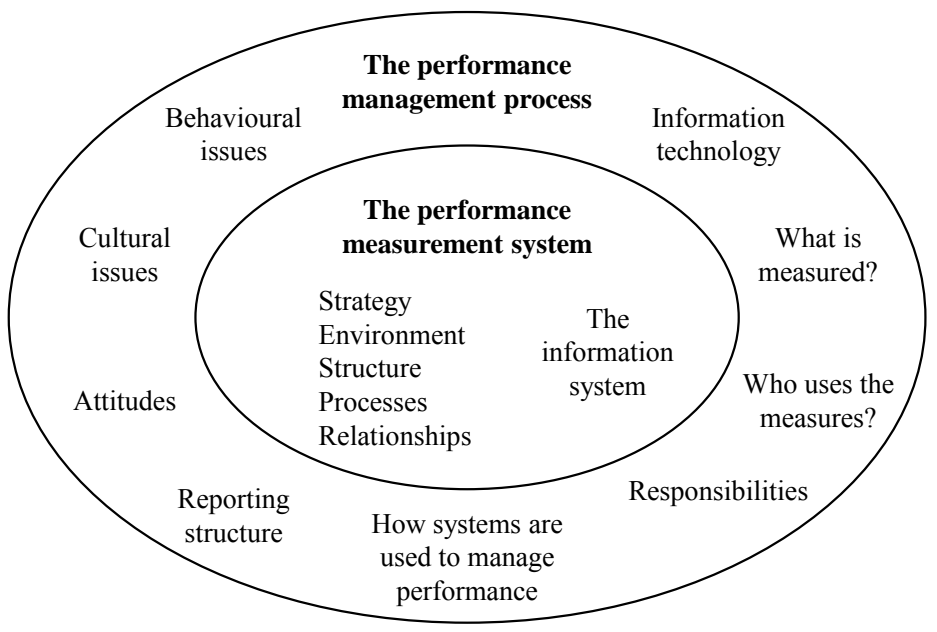

Figure 6 The performance management system and the position of the performance measurement system (Bititci et al., 1997) 
Both The Balanced Scorecard system and the Excellence models are examples of performance management systems whereas KPIs are used within the other systems and therefore are more in line with the definition of a performance measurement system.

However, in the construction industry, it is not uncommon that KPIs are used as a performance management system. That way of using KPIs has received some critique. Beatham et al. (2004) argues that most KPIs used in the construction industry are post event, lagging measures that do not provide the opportunity to make changes in the project that was measured. Bassioni et al. (2004) raises the issue that KPIs are used for benchmarking but do not give insight into the means of improving performance and therefore are of limited use for internal decision making. However, KPIs can be useful if they are used in the right way, as a tool in a performance management system. Both the balanced scorecard system and the Excellence Models use KPIs to measure performance. This indicates that KPIs can also be useful in a production strategy framework. In the following sections the balanced score card and the Excellence Models are described briefly and a more thorough investigation of KPIs in construction is presented.

\subsubsection{The balanced scorecard}

The Balanced Scorecard was developed to get a broader perspective on performance measurement. The traditional financial metrics, i.e. the financial perspective, were complemented with a customer perspective, an internal business perspective and an innovation and learning perspective. When financial measures were criticized, managers and academia had two options. Either to find new better financial measures to measure business performance or to rely on operational measures like cycle time and defect rates, which typically lead to good financial results (Kaplan and Norton, 1992). By introducing the four perspectives, including both financial and non-financial measures, managers do not have to choose between them. The Balanced Scorecard-measures give the managers a fast but comprehensive view of the business (Kaplan and Norton, 1992).

\subsubsection{Quality based excellence models}

Over the years many quality management models have been developed for the purpose of improving performance. The most utilized models are the European Foundation for Quality Management (EFQM) Excellence Model in Europe, the Malcolm Baldridge National Quality Award (MBNQA) in the United States and the Deming Prize in Japan (Bassioni et al., 2004). In the following the EFQM Excellence Model will be described briefly.

The EFQM Excellence Model was developed to understand the increasing business complexity, e.g. interdependencies between organisations, communities, countries and economies. It allows people to understand the cause and effect relationships between what actions their organisation takes and the results that it achieves. 
According to Dutt et al. (2012) the excellence model can for example be used:

- To help organisations develop measurable visions and goals

- To help companies understand the nature of the their business, the key linkages, and cause and effect relationships

- As a diagnostic tool for assessing the current help of the organisation

One of the general critiques of these kinds of systems is that they are to simple and do not simulate actual complexities of the business (Bassioni et al., 2004).

\subsubsection{Key performance indicators (KPI)}

The third method that is frequently used to measure performance in the construction industry is KPIs (Bassioni et al., 2004). KPIs is the collective term for performance metrics in the construction industry (Beatham et al., 2004).

Egan (1998), highlighted the importance of performance measurement and as a result of that report, the Construction Best Practice Programme (CBPP, 2002) launched KPIs for both project and organisational levels. The construction industry KPIs were first published in 1999, and are updated annually. Swan's and Kyng's (2004) report, that describes how to work with the KPIs defined by (CBPP, 2002), list 10 headline KPIs, see Table 6.

Table 6 KPIs (Swan and Kyng, 2004)

\begin{tabular}{|l|l|}
\hline KPI & Description \\
\hline Construction Cost & $\begin{array}{l}\text { Improvement of capital } \\
\text { cost year on year. }\end{array}$ \\
\hline Construction Time & $\begin{array}{l}\text { Improvement of time } \\
\text { year on year }\end{array}$ \\
\hline Predictability Cost & $\begin{array}{l}\text { Actual cost against the } \\
\text { cost predicted at tender. }\end{array}$ \\
\hline Predictability Time & $\begin{array}{l}\text { Actual time against the } \\
\text { time predicted at tender }\end{array}$ \\
\hline $\begin{array}{l}\text { Client Satisfaction } \\
\text { Product }\end{array}$ & $\begin{array}{l}\text { Client satisfaction with the } \\
\text { delivered product }\end{array}$ \\
\hline Client Satisfaction & $\begin{array}{l}\text { Client satisfaction with } \\
\text { the service provided by } \\
\text { the Project Team }\end{array}$ \\
\hline Defects & $\begin{array}{l}\text { Impact of the defects } \\
\text { of the final product }\end{array}$ \\
\hline Productivity & $\begin{array}{l}\text { Value added per person } \\
\text { working on the project }\end{array}$ \\
\hline Profitability & $\begin{array}{l}\text { Profitability of the } \\
\text { Construction Company }\end{array}$ \\
\hline Safety & $\begin{array}{l}\text { Accident Incident Rate } \\
\text { for the Company }\end{array}$ \\
\hline
\end{tabular}

Unfortunately the actual calculations of each KPI defined by the CBPP (2002) is not accessible unless you are a member organization and pay a member fee, hence other literature were reviewed to find KPIs. For reasons given above, performance and innovativeness are left out of the scope and in this study focus is on finding KPIs for the four competitive priorities cost, delivery, quality and flexibility. The headline KPIs in 
Table 6 represent cost (level and dependability) and delivery (speed and dependability) and quality (defects), flexibility is not represented by the headline KPIs.

Beatham et al. (2004) describe the use of KPIs in the construction industry and give examples of organisations that have developed KPIs for the construction industry and describe them briefly. In Table 7 KPIs presented by some of the organisations are categorized under each of the headline KPIs: quality, delivery (speed), delivery (dependability), cost (level) and cost (dependability), and also taking flexibility into account. 


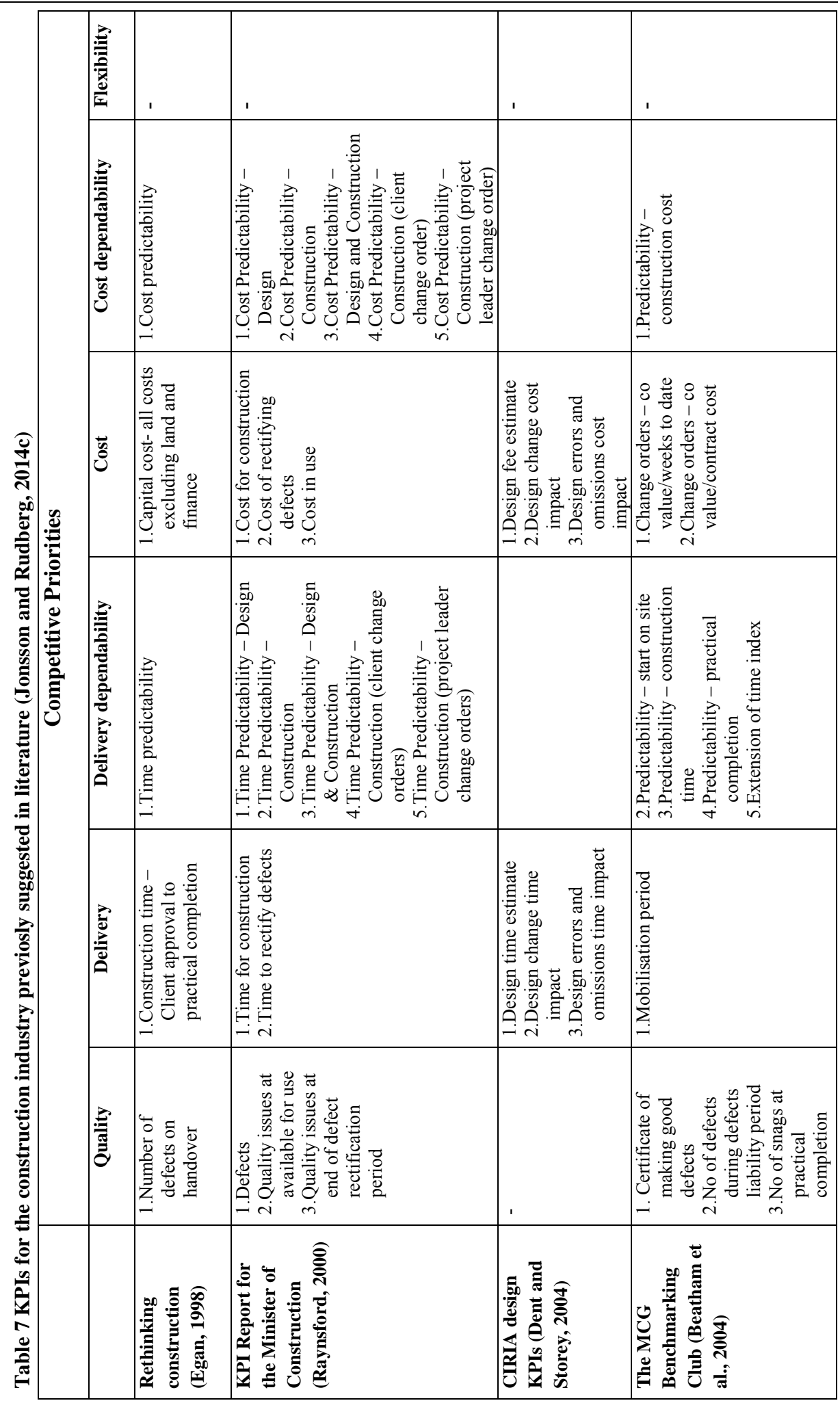


KPIs have been developed by other organisations than those presented in Table 7, for example The ACE consultants KPIs; Respect for people KPIs; Design Quality Indicator; Satisfaction of service KPIs (SoS KPIs). The reason for not including these organisations in the list of potential KPIs are twofold. Firstly they consider areas that are a bit out of the scope four this research and secondly they are not publically available and the providing organisations charged a fee to get access to the KPIs. The KPIs from these organisations will therefore not be further investigated.

Both Table 6 and Table 7 indicate that KPIs for measurement of the competitive priorities quality, delivery (speed and dependability) and cost (level and dependability) are defined for the construction industry. What becomes apparent is that there is a lack of metrics defined for flexibility adapted to a construction industry context. Therefore the flexibility is treated separately in the following.

Flexibility is an important aspect for all manufacturing companies. To be able to be competitive a company must be able to adapt to changing environmental influences. However, flexibility is a concept that is complex, multidimensional and hard to capture and over 50 different terms of various flexibility can be found in manufacturing literature (Sethi and Sethi, 1990).

To find KPIs for flexibility, traditional manufacturing strategy literature has been reviewed. Table 8 summarises suggested metrics from various production strategy literature.

Table 8 KPIs for flexibility (Jonsson and Rudberg, 2014c)

\begin{tabular}{|c|c|}
\hline Source & KPI for Flexibility \\
\hline Miltenburg (2005) & $\begin{array}{l}\text { 1. Number of products in the production line } \\
\text { 2. Number of available options } \\
\text { 3. Minimum order size } \\
\text { 4. Average production lot size } \\
\text { 5. Length of frozen schedule } \\
\text { 6. Number of classifications in the factory } \\
\text { 7. Average volume fluctuations that occur over a time period divided by } \\
\text { the capacity limit } \\
\text { 8. Ratio of number of parts processed by a group of machines to total } \\
\text { number processed by factory } \\
\text { 9. Number of setups } \\
\text { 10. Variations in key dimensional and metallurgical properties that the } \\
\text { equipment can handle } \\
\text { 11. Is it possible to produce parts in different machines }\end{array}$ \\
\hline Hill and Hill (2009) & $\begin{array}{l}\text { 1. Introduction of new products } \\
\text { 2. Handling a range of volumes } \\
\text { 3. Handling a range of products } \\
\text { 4. Meeting demand peaks }\end{array}$ \\
\hline Slack and Lewis (2011) & $\begin{array}{l}\text { 1. Product/service flexibility } \\
\text { 2. Volume flexibility } \\
\text { 3. Mix flexibility } \\
\text { 4. Delivery flexibility }\end{array}$ \\
\hline
\end{tabular}

The KPIs suggested by Hill and Hill (2009) are suggestions on what to measure, not how to measure, which we are looking for here. The KPIs suggested by Miltenburg (2005) are 
suggestions on how to measure process flexibility so they could potentially be used in a construction industry context. Taking a closer look at the KPIs suggested by Miltenburg (2005) KPI 1 and 2 are related to product mix but only measuring the number of products and available options do not tell us how good the production system handle the product mix. Measuring this merely tells us what the production system offer in terms of customization and not how well the production system handles this customization. The other metrics (3-11) are all developed to be used in the traditional manufacturing industry and they are hard to adapt to a construction industry context.

Turning to other parts of the operations management literature than production strategy, Rogalski (2011) narrows the scope down a bit and states that for a system, that measures flexibility, to be relevant it has to consider three types of flexibility, Volume, Mix and Expansion flexibility. The three types of flexibility is defined in (Rogalski, 2011):

The volume flexibility describes the capability of a short-term and economical capacity adaption for a given fabrication spectrum inside of the existing technical and organisational limitations of a production system (Rogalski, 2011 p. 30).

The mix flexibility characterizes the stability and consequently the mobility of a production system in abandoning single products or variations concerning the production spectrum, without endangering the economical product fabrication (Rogalski, $2011 \mathrm{p}$. $31)$.

The expansion flexibility describes the ability of a production system to increase its capacity, by changing elements and/or the structure of the system in a targeted way while also considering the economical benefit (Rogalski, 2011 p. 31).

In Rogalski (2011) it is stated that to achieve a generally accepted assessment system for measuring flexibility, it has to be applicable across industries. This indicates that the system presented in Rogalski (2011) might be useful also in the construction industry. Another factor that makes Rogalski (2011) interesting to investigate further is that it presents a system defining how to measure flexibility with a quantifiable evaluation procedure, not just qualitative estimations. 


\subsubsection{Summary performance measurement}

Based on the review of drivers and barriers for off-site production and KPIs for performance measurement the following manufacturing outputs are considered relevant to measure when evaluating the ability of different production systems ability to perform:

- Quality

- Delivery

- Speed

- Dependability

- Cost

- Level

- Dependability

- Flexibility

- Volume

- Mix

- Expansion

To measure performance in construction different methods have been used in the past and the three dominating systems is the balanced scorecard, excellence models and KPIs. The difference between the three is that the balanced score card and excellence models are performance management systems whilst KPIs are used for performance measurement. In a production strategy context a production strategy framework can be viewed upon as a performance management system and in such systems KPIs are argued to be useful to measure performance. 


\section{Research design}

This section describes the research process. The research design is described in a larger context to visualise the link between the different stages in the research process. The methods used in this research are described and finally the quality of the research is assessed in terms of validity and reliability.

\subsection{The research process}

In this thesis a production strategy framework for production of multifamily residences is presented. The production strategy framework that is developed and presented in this thesis consists of two parts. In the first part the focus is on the process choice (described in chapter 2) and the result is a classification matrix, corresponding to the product-process matrix (Hayes and Wheelwright, 1979). This part of the research is related to RQ1. In the second part, focus is on manufacturing outputs and performance measurement. This part of the research is related to RQ2 and RQ3. The research is inspired by traditional production strategy for the manufacturing industry and previous research in that field has been used and adapted to a construction industry context. The design of the production strategy framework, for production of multifamily residences, is inspired by the production strategy framework developed by Miltenburg (2005). Figure 7 visualises the two parts in Miltenburg's (2005) production strategy framework. The left hand part relates to the process choice (part 1) and the right hand part relates to manufacturing outputs and performance measurement (part 2).

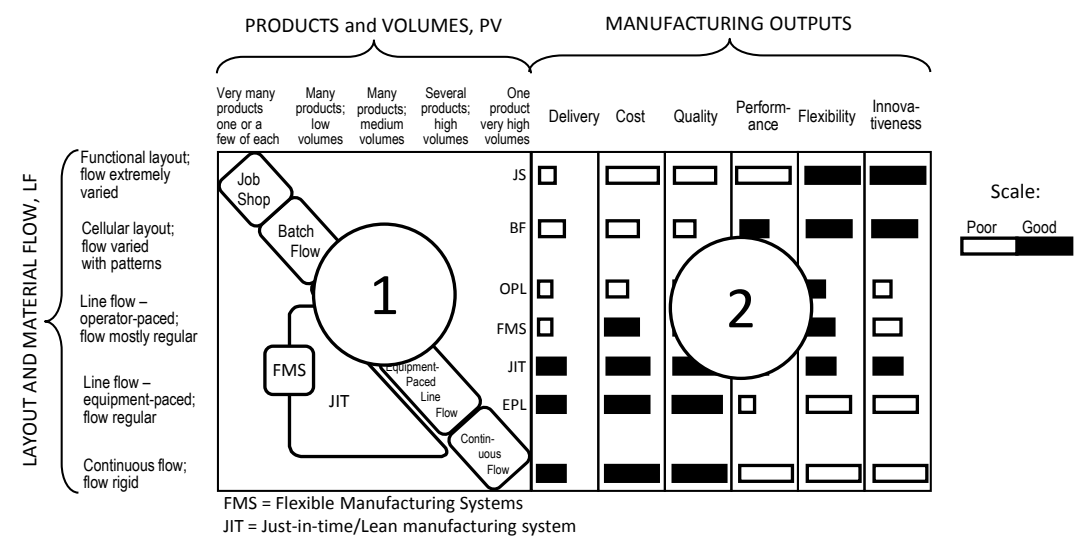

Figure 7 The two parts of this research project visualized in Miltenburg's (2005) production strategy framework 
The research process consists of three stages. In the first stage the theoretical constructs of this research were developed. In the second stage the theoretical constructs were assessed using case studies. In the third and final stage the theoretical constructs were refined and further developed using the input from case studies, results from the literature review and also some new data collected through interviews (Figure 8).

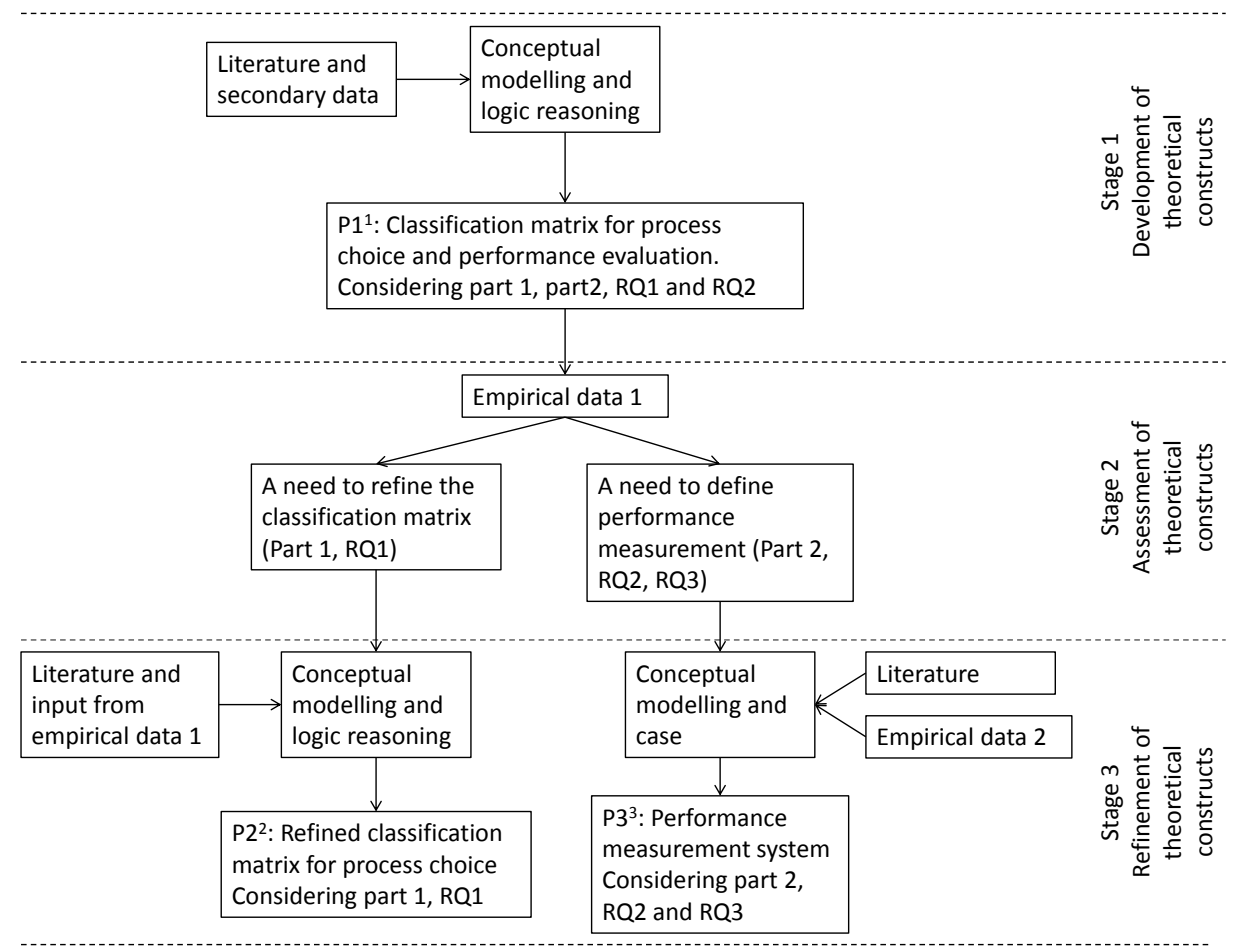

1. Paper 1 (Jonsson and Rudberg 2014a)

2. Paper 2 (Jonsson and Rudberg 2014b)

3. Paper 3 (Jonsson and Rudberg 2014c)

\section{Figure 8 The research process}

In the first stage the theoretical constructs of this research is developed. Results from the literature review and secondary data from three companies using different production systems for production of multifamily residences were used to develop a classification matrix corresponding to the left hand part of Figure 7. Two of the three companies used in stage 1 were also used in the case study in stage 2 and 3. In stage 1 the right hand part of Figure 7 was also considered by clustering drivers and barriers with off-site production and linking them to competitive priorities. The result from this first stage is a classification matrix for production of multifamily residences, offering the possibility to assess the relative ability of different types of production systems to perform in different areas of competition. 
In the second stage the initial idea was to map a number of production systems that are currently active in the house building industry in the classification matrix developed in stage 1 and evaluate their ability to perform in different areas of competition. This resulted in a conference publication (not included in this thesis) but also a list of shortcomings with the classification matrix. What also became clear was that there is a lack of well-defined performance measurement systems developed to evaluate the ability of the production function to perform.

In stage 3 the classification matrix developed in stage 1 was refined. To do this, the input from the case studies and the results from the literature review were used. The dimensions in the matrix were revised to be better adapted to a construction industry context. Secondly a performance measurement system was developed. To do this a literature review and logic reasoning were used to define KPIs for different areas of competition. The defined KPIs were then validated through empirical data from the case companies. This performance measurement system provides a possibility to evaluate different production systems based on quantitative data which will facilitate comparison between different production systems and also gives the companies the possibility to measure how the performance changes over time.

\subsubsection{Publication strategy}

The research process describes the output of each stage in the research process in terms contributions, i.e. the classification matrix and the performance measurement system. The results of the research have been presented in a number of papers and the following section describes the publication strategy for this research. This is done to further clarify how the final results presented in this thesis have evolved over time.

Stage 1 resulted in a conference paper that, after the conference, was improved, extended and published in Construction Management and Economics. Stage 2 resulted in a conference paper (not included in this thesis) in which an attempt to classify and evaluate the performance of different production systems was made. This paper made it clear that the classification matrix had to be revised and that a performance measurement system had to be developed. The third stage resulted in two papers, the first is under review for publication and the second is a working paper. The papers, related to the research process, are presented in Figure 9. 


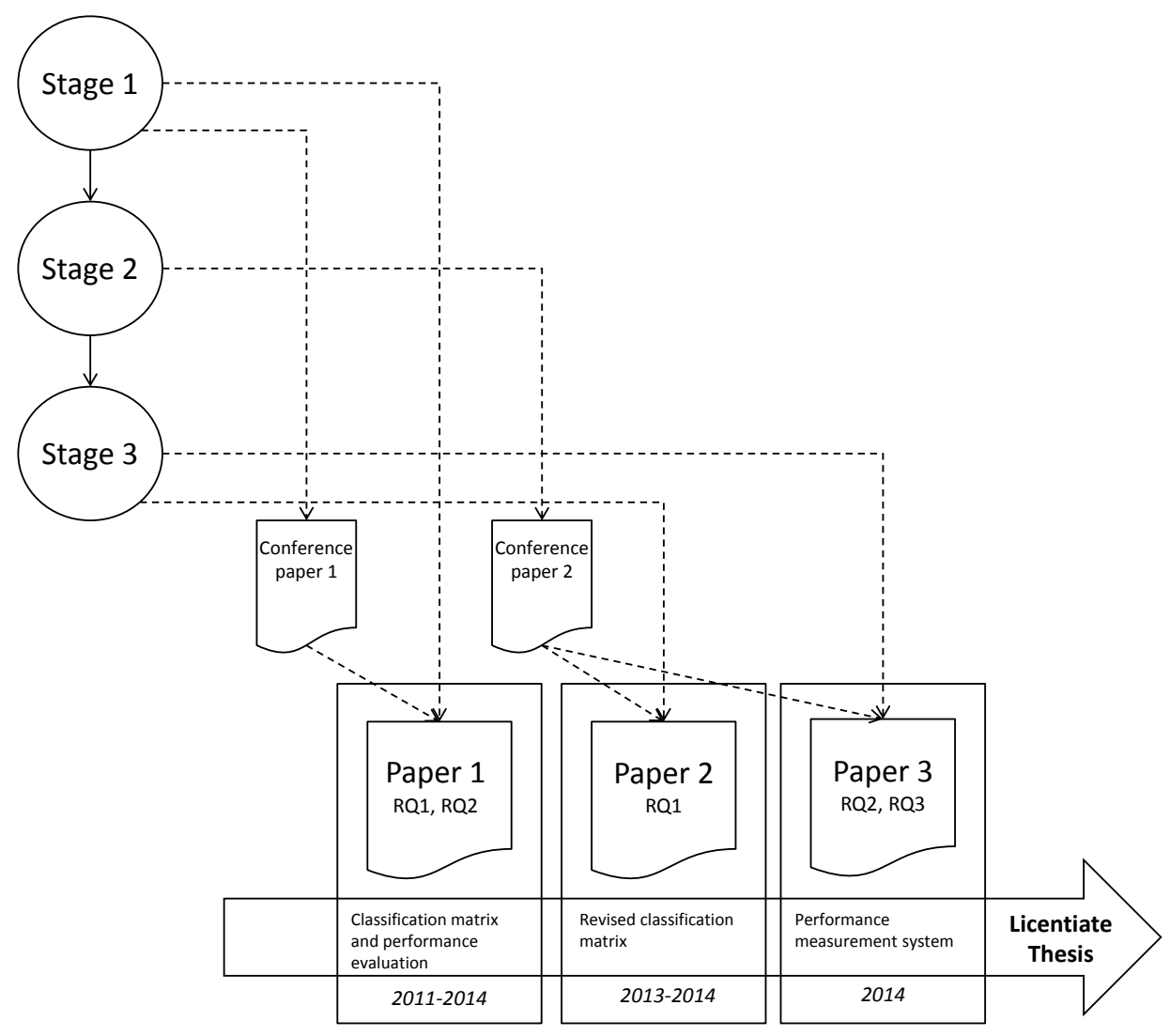

Figure 9 Papers produced during the research process

The three research questions are addressed in different stages of the research and each paper focus on different research questions. This is visualised in Figure 8 and Figure 9.

\subsubsection{Author's Statement}

All three papers included in this thesis are authored by the thesis author and the author's main supervisor.

In Jonsson and Rudberg (2014a), in this thesis referred to as Paper 1, both authors contributed equally to the publication. However, the author of this thesis took main responsibility for the literature review and data compiling and the main supervisor the overall responsibility for structure and writing of the actual paper.

In Jonsson and Rudberg (2014b), in this thesis referred to as Paper 2, the author of this thesis took a larger responsibility both for performing the case study and for the writing process. The main supervisor contributed with overview discussion and writing.

In Jonsson and Rudberg (2014c), in this thesis referred to as Paper 3, the author of this thesis had a major role in both developing the performance measurement system, conducting the interviews with the case companies as well as in writing the paper. The 
main supervisor contributed with overview discussion, additional literature review concerning flexibility measurement and writing.

\subsection{Choice of method}

The initial intention for this research was to use a deductive research approach. The logical conclusions (i.e. theoretical constructs) derived from theory (i.e. the literature review in Stage 1) were supposed to be tested in an empirical setting (Stage 2) and based on this present general conclusions. However, the test in an empirical setting did not match the theoretical constructs developed in Stage 1. This started a creative iterative approach to find new matching literature to extend the theoretical constructs defined prior to the empirical test. This is more in line with abductive reasoning (Kovács and Spens, 2005) where an iterative approach between theory and empirical data is used.

This abductive research consists of two main research methods: conceptual modelling based results from a literature review and secondary data, and case study. Conceptual modelling is used in stage 1 and stage 3, of the research process. In stage 1 the results from the literature review and secondary data were used to develop the theoretical constructs of the research. In stage 3 conceptual modelling based on the results from a literature review and input from the case study were used to refine the theoretical constructs developed in stage 1 . In stage 2 , case study was used to assess the theoretical constructs developed in stage 1 .

\subsubsection{Case study}

For the empirically grounded part of this research, stage 2 and 3, case based research was chosen as the primary research method. In stage 1 secondary data, in terms of published papers, reports and publically available data, about three different production systems were used to validate the findings in Jonsson and Rudberg (2014a). In stage 1 theoretical replication was used and the three case examples were chosen to represent different types of production systems. Even though some interviews were conducted in stage 1 the case study described below refers to the work conducted in stage 2 and stage 3 .

As mentioned above case studies has been argued to be a good method to follow-up previous research, e.g. survey-based research or, as in this instance, the results derived from a literature review and conceptual modelling (Karlsson, 2009). Case research can also be used for theory extension/refinement (Yin, 2009), as is the intention in this study. When selecting cases for theory building research each case should be selected to either predict similar results (literal replication), i.e. cases are chosen for statistical reasons (Eisenhardt, 1989), or to produce contrary results but for predictable reasons (theoretical replication) (Karlsson, 2009). In this study theoretical replication is used and a screening of the industrialized construction sector in Sweden was made to identify suitable cases for the study. Persons involved in the industrial building sector have been consulted, both from academia and from the industry, and this resulted in a list of potential candidates. 
From this list, seven concepts (production systems) were selected so that they would represent different types of production systems, in terms of product and process characteristics, thereby offering the possibility to expose differences and similarities between different production systems (predictable differences/similarities in line with the idea of theoretical replication). All seven companies accepted to participate in the research and they were visited for an initial interview and factory visit. After these initial visits, two of the companies were left out since they did not produce whole buildings as a contractor, but rather acted as supplier/sub-contractor for another main contractor. The unit of analysis is thereby the production system and the cases in this study consist of different production systems for production of multifamily residences (whole buildings, being the main contractor).

The data for the five remaining cases was collected on two occasions. The first round of data was collected through on-site visits, review of company documents, and semistructured interviews with persons involved in developing and managing the different production systems. Each company visit consisted of a general presentation of the company and production system (from their part), a presentation of the research project (from our part), a tour in the factory where the prefabrication of building components was performed and an interview with one or more persons, at management level, with knowledge about the concept. An interview protocol with predetermined questions was used in all interviews to be able to compare the different production systems and to ensure reliability. The questions in the interview protocol were related to four main topics:

- Background and general facts about the firm and their concept for producing multifamily residences

- The production system

- The product

- The market (clients and competitors)

The first bullet aims to give a general understanding of the firm and the related production system. The second and third give detailed information about the product and process characteristics respectively. The fourth bullet gives an indication on how the firm handle market requirements from clients and competitors. After each visit the data was transcribed and compiled. If some information was missing additional interviews were performed by phone and e-mail. A more thorough description of each case is given in Jonsson and Rudberg (2014b).

The second round of data was collected through telephone interviews with the case companies. An interview protocol with predetermined questions was sent to the respondents in advance so that they could prepare for the interview. The interview consisted of three parts. The first part focused on performance measurement in general within the construction industry and more specifically on how they worked with performance measurement within their concept. This part of the interview gave insight in how the companies measured the ability of the production system to perform. The second part consisted of a discussion and validation of the theoretically defined metrics derived 
from performance measurement literature. This part of the interview was performed to be able to see if the derived metrics could be useful to the case companies. It was also used to refine some of the suggested metrics so that they would be in line with already established terms and metrics used in the construction industry. The third part of the interview focused on the feasibility of the metrics i.e. if the companies had access to all the necessary data to be able to use the suggested metrics. This part of the interview is important since, for any performance measurement system to be successful, the data should be easy to collect (Beatham et al., 2004). After collecting and compiling the data from the interviews, the drafts were sent back to the respondents for review to ensure for reliability.

\subsection{Judging the quality of the research}

In case study research it is particularly important to pay attention to reliability and validity (Karlsson, 2009). Yin (2009) describes four "tests" to asses three dimensions of validity (i.e. construct validity, internal validity and external validity) and reliability. Internal validity is mainly a concern for explanatory research and since this research project is explanatory the internal validity is considered important. Table 9 describes means to ensure validity and reliability.

Table 9 Means to ensure validity and reliability (Yin, 2009 p. 41)

\begin{tabular}{|c|c|c|}
\hline Test & Case study tactic & $\begin{array}{l}\text { Phase of research in which } \\
\text { tactic occurs }\end{array}$ \\
\hline Construct validity & $\begin{array}{l}\text { - } \quad \text { Use multiple sources of evidence } \\
\text { - } \quad \text { Establish chain of evidence } \\
\text { - Have key informants review drafts of case } \\
\text { study report }\end{array}$ & $\begin{array}{l}\text { Data collection } \\
\text { Data collection } \\
\text { Composition }\end{array}$ \\
\hline Internal validity & $\begin{array}{ll}\text { - } & \text { Do pattern matching } \\
\text { - } & \text { Do explanation building } \\
\text { - } & \text { Address rival explanations } \\
\text { - } & \text { Use logic models } \\
\end{array}$ & $\begin{array}{l}\text { Data analysis } \\
\text { Data analysis } \\
\text { Data analysis } \\
\text { Data analysis }\end{array}$ \\
\hline External validity & $\begin{array}{l}\text { - Use theory in single-case studies } \\
\text { - } \quad \text { Use replication logic in multiple-case } \\
\text { studies }\end{array}$ & $\begin{array}{l}\text { Research design } \\
\text { Research design }\end{array}$ \\
\hline Reliability & $\begin{array}{ll}\text { - } & \text { Use case study protocol } \\
\text { - } & \text { Develop cases study database }\end{array}$ & $\begin{array}{l}\text { Data collection } \\
\text { Data collection }\end{array}$ \\
\hline
\end{tabular}

In the following each dimension of validity and reliability is assessed related to the research process described above.

Construct validity is defined as having the right measures for a studied object (Yin, 2009). To ensure construct validity in this study:

- Data has been collected from multiple sources, review of publicly available information, interviews, archival data etc.

- The iterative process going from findings from the literature review to empirical data back to theory for development and further refinement of the constructs should strengthen the construct validity of the research

- After the data collected through interviews had been compiled the draft of the research protocol was sent to the respondents for review. 
Internal validity is the confidence that can be placed in the cause and effect relationship in a study (Yin, 2009) i.e. can there be an alternative cause, than the one presented, that explain the observations and results. To ensure internal validity:

- Alternative explanations have been considered and valued throughout the research process.

- In this research the empirical data was matched with predicted results in terms of conceptual models derived from literature. This is in line with the description of pattern matching given in Yin (2009) and also a way to strengthen the internal validity of this study.

- One thing that decreases the internal validity is that the ability of the case companies to deliver manufacturing outputs has not been measured. This is due to limited access to the case companies. The effect is that no quantitative evaluation of how the position in the suggested classification matrix affects the ability of a production system to perform could be done.

External validity describes to what extent the findings in the study can be generalized beyond the immediate case (Yin, 2009). To achieve external validity in this study:

- The approach is in line with theoretical replication where the results from the multiple case study exposes differences between different production systems but for predictable reasons.

- The sample of cases was deliberately chosen to represent different types of production systems for production of multifamily residences. This makes the findings generalizable in a construction industry context. However the sample of case companies is small and to be sure that the results, the classification matrix and the performance measurement system, can be used for all types of production systems for production of multifamily residences a larger sample of case companies is needed. However, since the findings are useful to the four different production systems defined in this study, the external validity is considered good.

Reliability means that the operations of a study, i.e. the research process, can be repeated with the same results (Yin, 2009), in this study the reliability is ensured by:

- Using a structured and well prepared research protocol when collecting case study data.

- Storing the drafts of the interviews digitally in a database, so that it can be reviewed and controlled. Hard copies of the notes taken during the interviews, underlying the drafts are also stored.

- A thing that should be considered related to the reliability of the research is that the data from the cases are collected and analysed by specific persons. To know if the results had been exactly the same if the study had been performed by another researcher is more or less impossible. The main findings however should be the same independent of who is doing the research.

By describing the research process in detail and also account for the process of ensuring validity and reliability, hopefully the research design is transparent enough to be considered trustworthy. 


\section{Summary of papers}

In this chapter each of the three papers included in this thesis are summarised. The content and contribution of each paper is presented.

\subsection{Summary of paper 1}

The purpose of this paper (Jonsson and Rudberg, 2014a) is to develop a matrix for classifying production systems for construction with various degrees of off-site production. In line with traditional production strategy frameworks, the link between market requirements and the production systems is visualised by evaluating how the product and process characteristics affect the production systems ability to deliver manufacturing outputs. Relating back to the research design this paper is the first stage of the research process and both part 1 and part 2 (Figure 7) are included in this paper.

Previous attempts to classify off-site production systems for construction focus on dimensions such as the design process, the product technology, or the supply chain structure, but none of them acknowledge the importance of how orders are actually won in the market and that different market segments have different requirements. Using production strategy theory as a base, a framework is derived from the results of a literature review linking market requirements, via the product offering, to the design of the production system (Figure 10). The matrix (left hand side of Figure 10) positions typical production systems based on their respective degree of product standardization and volumes relative the degree of off-site production. Similar to production systems in manufacturing, also production systems for construction deliver manufacturing outputs at different levels, indicating that the choice of production system will affect the competitiveness of the company. The result of this paper is the framework presented in Figure 10 . 


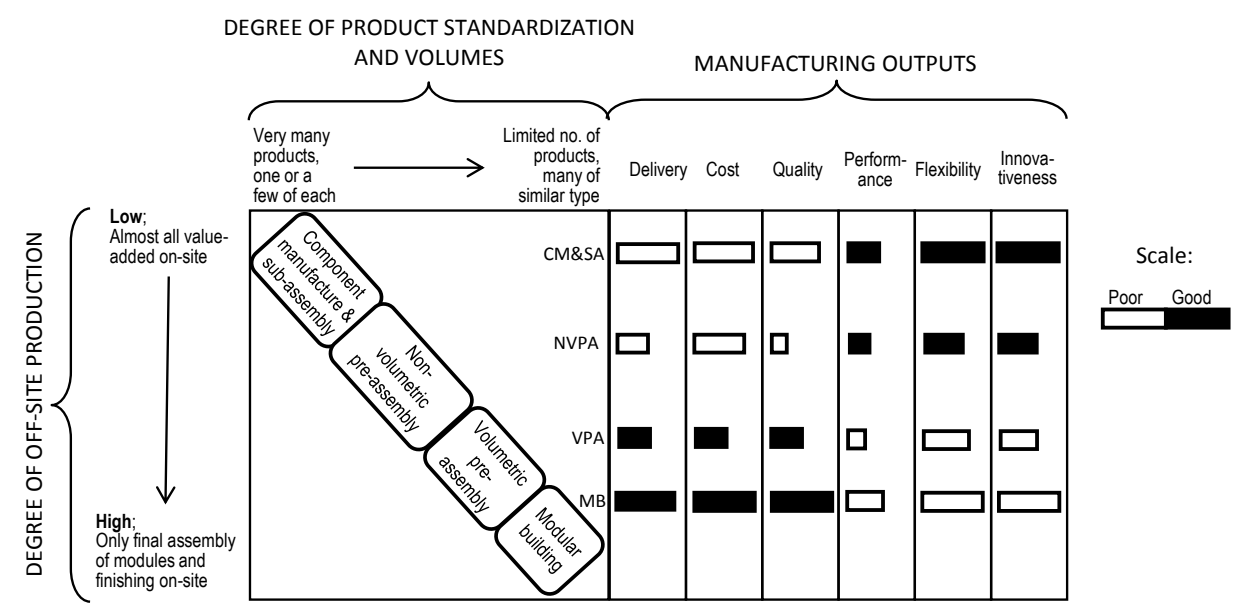

Figure 10 Classification framework presented in (Jonsson and Rudberg, 2014a)

The applicability of the framework is exemplified through three case illustrations of offsite production systems, and it shows that the framework can be used to analyse the relative strengths and weaknesses of a production system. The framework can also be used as a guide when developing new, or adjusting existing, production systems for production of multifamily houses so that they will match market requirements and offer competitiveness.

The main contribution lays in that the paper:

- Provides a matrix that aids to classify and compare different kinds of production systems in a structured way and to show how they fit different market conditions and requirements.

- Illustrates the different facets of industrialized production systems and their relative strengths and weaknesses.

- Introduces a contingency-based and market oriented approach to the design of production systems for industrialized building, linking market requirements, via the product offering, to the design of the production system.

- Provides cases that exemplify how the framework can be used and how different production systems can be compared.

\subsection{Summary of paper 2}

The initial idea of this paper (Jonsson and Rudberg, 2014b) was to test the framework proposed in paper 1 on empirical data based on a set of case studies. Yet, when the cases were difficult to classify in the matrix this raised questions on the definitions of the two dimensions in the matrix and the use of Gibb's (2001) four generic production systems as a basis to classify production systems. Thereby this research turned into an iterative, abductive, process going between the empirical case data and a further theorethical development of the matrix presented in paper 1 (Jonsson and Rudberg, 2014a). This paper focuses on part 1 of the research (Figure 7) and the classification matrix is refined (Stage 
3 in Figure 8) using literature and input from the case studies conducted in stage 2 (Figure 8).

The major changes made to the classification matrix in paper 1 (Jonsson and Rudberg, 2014a) are:

- Introduced Lampel's and Mintzberg's (1996) five categories of customisation instead of the floating scale of degree of product standardisation and production volumes. The five categories are:

- Pure standardisation refers to the case in which the end product is the same and where the customer does not get involved before taking possession of the product.

- In segmented standardisation, firms respond to the needs of different clusters of customers but the product for each cluster is standardized.

- In customized standardization, products are made to order from standardized components, this can also be called standardized customization, modularisation or configuration.

- Tailored customization requires a basic product that can be customized in the fabrication stage.

- In pure customization the product is customized from scratch

This way of defining different degrees of product standardization facilitates the classification by using fixed segments for classifying the production systems' product characteristics.

- Used Gibb's (2001) four generic production systems as means to classify the production systems' process characteristics. This introduced fixed categories in terms of the degree of off-site production.

- Two out of Gibb's (2001) four generic production systems were slightly adjusted to better reflect the companies producing whole buildings as the main contractor:

- Prefabrication \& Pre-assembly (PF\&PA) replaced Gibb's Volumetric Preassembly (VPA). PF\&PA is a situation not only including a high degree of prefabrication, but also some degree of pre-assembly off-site.

- Gibb's Non Volumetric Pre-assembly (NVPA) was renamed to Prefabrication \& Sub-assembly (PF\&SA) to better follow the terminology of the matrix, however the description of this type production system correspond directly to VPA.

- The fixed positions along the diagonal was removed to better reflect that all companies, deliberately or by accident, do not have a perfect match between the product and process characteristics, but can still perform well if the deviation is managed correctly.

The result of these changes is the classification matrix presented in Figure 11. 


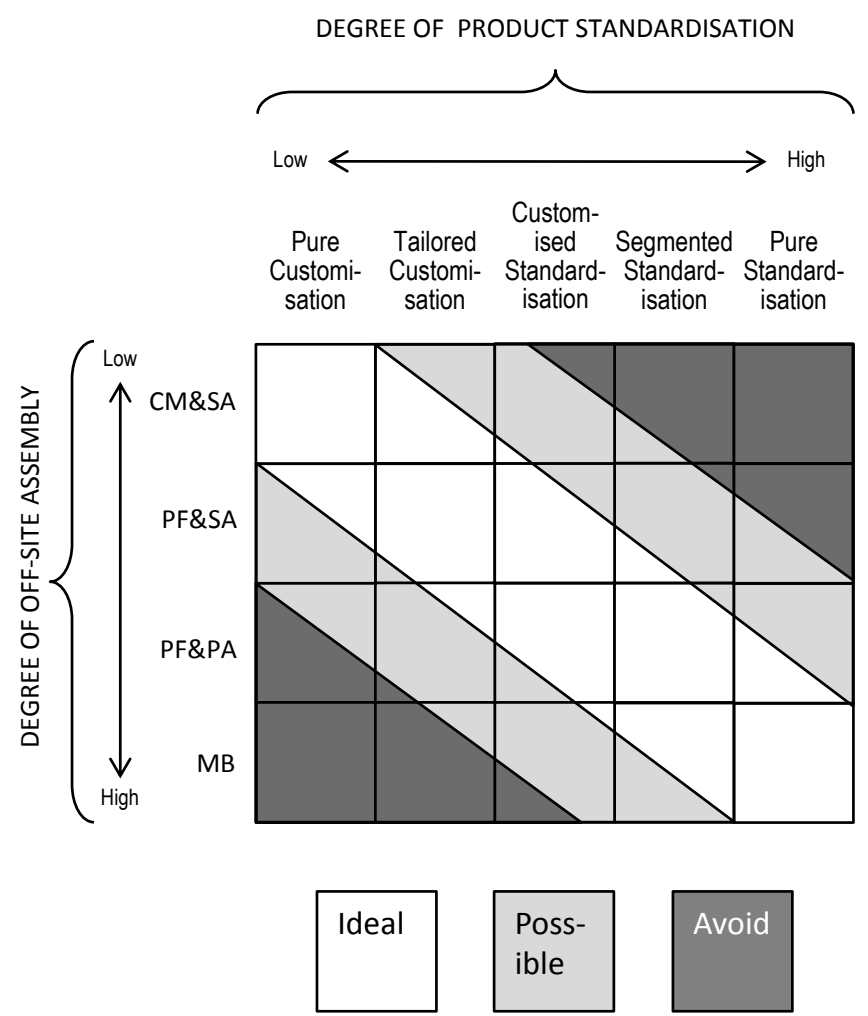

Figure 11 Revised classification matrix presented in paper 2 (Jonsson and Rudberg, 2014b)

The main contribution in this paper is the classification matrix (Figure 11). The changes made compared to the classification matrix developed in Jonsson and Rudberg (2014a) should make the matrix more straightforward to use and thereby facilitate the categorisation, and mapping, of different production systems for production of multifamily residences. The categorization of different types of production systems can be used to guide the decision-making process when designing new, or re-designing existing, production systems in construction. Yet, to understand this more thoroughly the matrix must be complemented with a part analysing the relative ability of the production systems to deliver manufacturing outputs at competitive levels. The revised classification matrix should therefore be viewed upon as a first step in the process of developing a production strategy framework adapted to a construction industry context.

\subsection{Summary of paper 3}

In this paper (Jonsson and Rudberg, 2014c) the focus is on performance measurement and defining quantitative metrics for different manufacturing outputs that can be used to evaluate different production systems in a structured way. The purpose is consequently to develop a system for performance measurement in construction with defined metrics for each manufacturing output respectively. In this paper focus is on part 2 of the research 
(Figure 7). The metrics can be used to find out how different production systems perform in different areas of competition.

The research process is divided into two phases. In the first phase, the results from a literature review is used to define what to measure, i.e. which manufacturing outputs that have to be taken into consideration when evaluating a production system in the construction industry. After deciding what to measure, quantitative metrics are defined, for each manufacturing output. The result is a system defining what and how to measure performance of production systems in construction.

The suggested metrics are validated using empirical data collected through additional interviews conducted with the same case companies that were used in stage 2 and paper 2. The respondents gave their opinion on the suggested metrics and also accounted for how they work with performance measurement within each concept. The result of this deductive approach is a performance measurement system that is grounded in both theory and practice. The defined KPIs are presented in Table 10.

Table 10 KPIs for measuring production system performance in the construction industry

\begin{tabular}{|c|c|}
\hline $\begin{array}{l}\text { Competitive } \\
\text { priority }\end{array}$ & KPI \\
\hline Quality & $\begin{array}{l}\text { Quality for the } i \text { : th project }\left(Q_{i}^{p}\right)= \\
\qquad=\frac{\text { Cost for rectifying defects in project } i}{\text { Total production cost for project } i} \times 100 ; i=1,2, \ldots, n \\
\quad \text { Quality concept }\left(Q^{C}\right)=\frac{\sum_{i=n-N+1}^{n} Q_{i}^{p}}{N} \\
\begin{array}{l}i=\text { Project index (running numbers) } \\
N=\text { Number of projects included in the moving average calculation }\end{array}\end{array}$ \\
\hline $\begin{array}{l}\text { Delivery } \\
\text { speed }\end{array}$ & $\begin{array}{l}\text { Delivery speed for the } i \text { : th project }\left(D S_{i}^{p}\right)= \\
\qquad=\frac{\text { Total production time for project } i}{\text { Total gross floor area for project } i} ; i=1,2, \ldots, n \\
\quad \text { Delivery speed concept }\left(D S^{C}\right)=\frac{\sum_{i=n-N+1}^{n} D S_{i}^{p}}{N} \\
\quad \begin{array}{l}i=\text { Project index (running numbers) } \\
N=\text { Number of projects included in the moving average calculation }\end{array}\end{array}$ \\
\hline $\begin{array}{l}\text { Delivery } \\
\text { dependability }\end{array}$ & 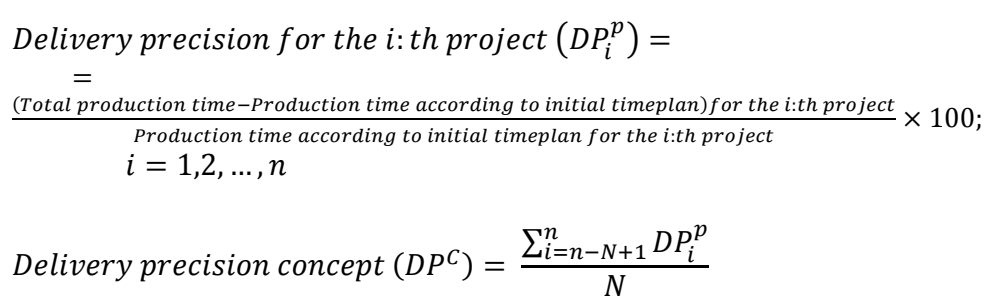 \\
\hline
\end{tabular}




\begin{tabular}{|c|c|}
\hline & $\begin{array}{l}\text { Delivery dependability concept }\left(D P^{D}\right)= \\
\qquad=\frac{\text { Number of projects delayed out of } M \text { projects }}{M} \times 100 \\
i=\text { Project index (running numbers) } \\
N=\text { Number of projects included in the moving average calculation } \\
M=\text { Number of projects that is to be taken into consideration (can be different from } N \text { ) }\end{array}$ \\
\hline Cost level & $\begin{array}{l}\text { Cost level for the } i \text { : th project }\left(C L_{i}^{p}\right) \\
\qquad \begin{array}{l}\text { Total production cost for project } i \\
\text { Total gross floor area for project } i\end{array} \\
\qquad \begin{array}{l}\text { Cost level concept }\left(C L^{C}\right)=\frac{\sum_{i=n-N+1}^{n} C L_{i}^{p}}{N} \\
\quad N=\text { Project index (running numbers) } \\
N=\text { Number of projects included in the moving average calculation }\end{array}\end{array}$ \\
\hline $\begin{array}{l}\text { Cost } \\
\text { dependability }\end{array}$ & 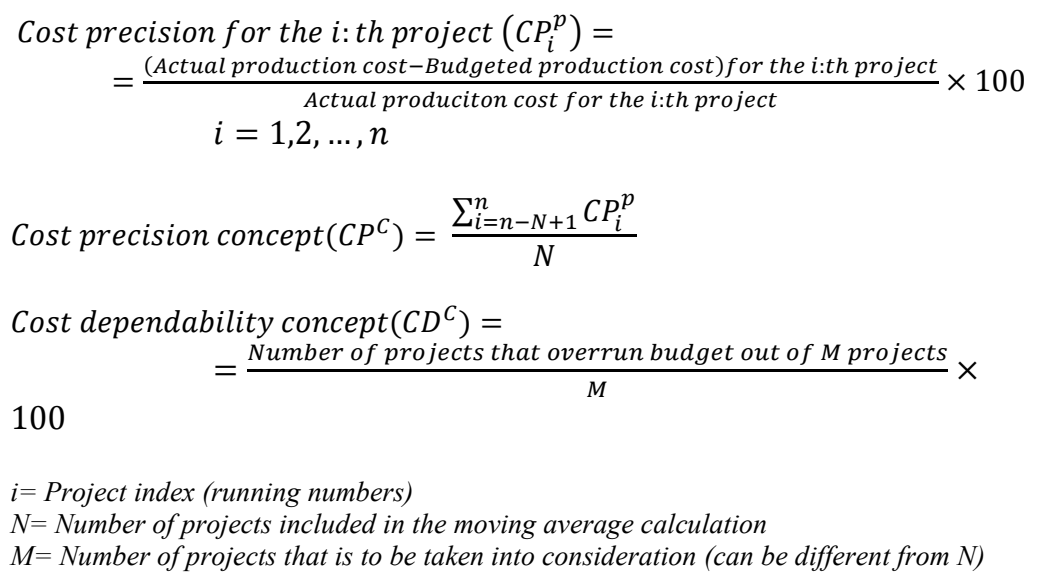 \\
\hline $\begin{array}{l}\text { Volume } \\
\text { flexibility }\end{array}$ & $\begin{array}{l}\text { Volume flexibility concept }\left(V F^{C}\right) \\
\quad=\text { Maximum capacity - Volume at Breakeven Point }\end{array}$ \\
\hline $\begin{array}{l}\text { Mix } \\
\text { flexibility }\end{array}$ & $\begin{array}{l}\text { Mix flexibility concept }\left(M F^{C}\right)=\frac{\sum_{i=n-N+1}^{n} \Delta C M_{i}^{p}}{N} \\
i=\text { Project index (running numbers) } \\
\Delta C M_{i}^{p}=\text { the relative deviation from the contributing margin of the optimal project for } \\
\text { project } i \\
N=\text { Number of projects included in the moving average calculation }\end{array}$ \\
\hline $\begin{array}{l}\text { Expansion } \\
\text { flexibility }\end{array}$ & $\begin{array}{l}\text { Expansion flexibility }\left(E F^{C}\right) \\
\quad=\text { Tageted capacity - Volume at Breakeven Point (new) }\end{array}$ \\
\hline
\end{tabular}


From a production strategy perspective it is concluded that the most suitable way of measuring performance is to use well defined KPIs for each manufacturing output. KPIs are often used for performance measurements in performance management systems, e.g. Balanced Scorecard or different Excellence Models, this indicates that using KPIs in a production strategy framework is appropriate.

The main contribution of this paper is that it:

- Defines what should be taken into consideration when evaluating production systems for production of multifamily residences.

- Suggests how to measure the ability of a production system to perform in different areas of competition

- Presents a list of, quantitative, KPIs, grounded in both theory and practice, for each manufacturing output 


\section{A framework for production strategy in construction}

The purpose of this research is to develop a production strategy framework for production of multifamily residences. In this chapter the research questions are answered and the content of the framework is presented. After describing the content a description of how the framework can be used is given.

\subsection{Research questions}

The purpose of this research is to, from a production strategy perspective, develop a framework that links the design of a production system, in terms of process and product characteristics, to the ability of the production systems to perform in different areas of competition. To develop this production strategy framework three research questions were formulated.

The first research question (RQ1) is formulated:

What dimensions can be useful, from a production strategy perspective, when classifying different production systems for the production of multifamily residences?

From a production strategy perspective it would be useful to classify different production systems along the dimension Degree of Product Standardisation. In this dimension Lampel's and Mintzberg's (1996) five customisation strategies ranging from Pure Customisation, via Tailored Customisation, Customized Standardisation, Segmented Standardisation, to Pure Standardisation are used to define each step along the $\mathrm{x}$-axis in the classification matrix (Figure 11). The other dimension that would be useful is related to the process characteristics of the production system. Along this dimension the production systems are classified based on the Degree of Off-site assembly. In this dimension, adjusted versions of Gibb's (2001) four generic production systems are used to define each step along the y-axis. The four generic production systems are Component Manufacturing \& Sub-assembly (CM\&SA), Prefabrication \& Sub-assembly (PF\&SA), Prefabrication \& Pre-assembly (PF\&PA) and Modular Building (MB). The dimensions described give a good representation of how multifamily residences are produced in the construction industry and should be quite straightforward to use and thereby facilitate the categorisation and mapping of different production systems for production of multifamily residences. 
The second research question (RQ2) is formulated:

What manufacturing outputs/competitive priorities have to be taken into consideration when evaluating different production systems for production of multifamily residences?

To answer this question, traditional production strategy literature and literature concerning drivers and barriers for off-site production in construction was reviewed. Based on the review, four competitive priorities were defined as important when evaluating production systems for the production of multifamily residences, Delivery, Cost, Quality and Flexibility. The manufacturing output Delivery was then further divided into Delivery speed and Delivery dependability (Slack and Lewis, 2011) and in line with that Cost was divided into Cost level and Cost dependability. Flexibility was divided into three categories based on Rogalski (2011), Volume flexibility, Mix flexibility and Expansion flexibility.

The third and final research question (RQ3) is formulated:

How should the ability of a production system to deliver manufacturing outputs be measured?

From a production strategy perspective KPIs are a useful tool to measure performance for different productions systems in the construction industry. Since there is a lack of welldefined KPIs in existing literature, KPIs for each competitive priority was defined and validated through empirical data. The defined KPIs are listed in Table 10.

\subsection{Content of the production strategy framework for construction}

The production strategy framework presented in this thesis is built around two parts (Figure 7). The first part is a classification matrix (Jonsson and Rudberg, 2014b) in which different production systems can be positioned based on their product and process characteristics (Figure 11). For the classification matrix to be useful it has to be related to the ability of the production system to perform in different areas of competition. The second part of the framework is therefore related to performance measurement (Jonsson and Rudberg, 2014c). Figure 12 is a suggestion of how such a production strategy framework could be designed. 


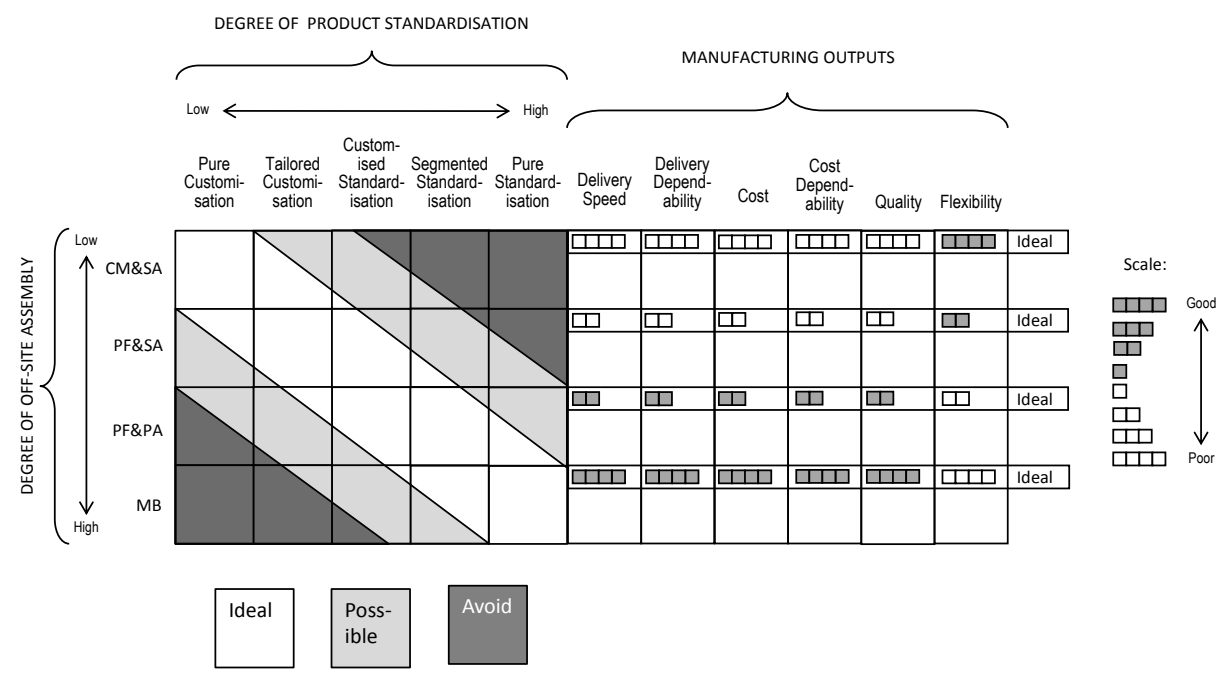

Figure 12 Tentative production strategy framework for construction

The left hand part of the framework is the classification matrix for production systems in construction presented in Jonsson and Rudberg (2014b). The right hand part of the framework is a suggestion of how part 2 (Figure 7) of the framework can be designed. This part is inspired by how Miltenburg (2005) present the ability of different production systems for manufacturing to deliver manufacturing outputs in different areas of competition. The manufacturing outputs that should be taken into consideration when evaluating different production systems in construction, i.e. delivery (speed and dependability) cost (level and dependability) quality and flexibility is represented in this part of the framework. The scale, indicating the level of performance, range from good to poor and is represented by grey and white squares. For the ideal positions in the matrix, i.e. where there is a match between the degree of off-site assembly and the degree of product standardisation, qualitative estimations of the performance is made in the right part of the framework. The results from the literature review indicate that an increased degree of off-site production has a positive effect on the ability of the production system do perform in the areas delivery, cost, and quality, but a negative effect on flexibility.

The right hand part of the framework presented is not complete but merely a suggestion on how this part of the production strategy framework could be visualised. The defined KPIs in Table 10 (Jonsson and Rudberg, 2014c) are the first step in developing this part further. 
If the quantitative data, collected using the defined KPIs, can be related to the scale, ranging from good to poor, the framework (Figure 12) can be used in a number of ways, for example:

- Analyse the current production system

- Analyse end evaluate different production systems for production of multifamily residences

- Analyse competitors' production strategies

- As decision support when designing or redesigning production systems

How to use the framework, i.e. the process, is described in the next section.

\subsection{Process of the production strategy framework for construction}

The process of using the production strategy framework for production of multifamily residences (Figure 12) is similar to the process of using Miltenburg's (2005) production strategy framework (described in chapter 2.1.3). If, for example, the framework is to be used to analyse and change an existing production system, the process of doing this follows three steps.

In step one the status of the current production system is defined by positioning the production system in the classification matrix. In this step the match between the product and the process characteristics is visualized. If there is a good match the production system will be located on, or near, the diagonal of the classification matrix and if there is a mismatch the production system will be located off the diagonal. A mismatch in this first step should be considered a risk for the business and given further attention. There are four ways to handle a mismatch in the classification matrix (Hill and Hill, 2009):

1. Live with the mismatch, at least you are aware of it and hopefully can handle the risk.

2. Move towards the diagonal by adjusting the product characteristics that is adjust the market strategy to better suit the existing production process.

3. Move towards the diagonal by changing the production process to better match the existing market strategy.

4. A combination of alternative two and three.

The second step is to make an analysis of the market. This is done to determine the order winning and qualifying outputs that the production system must provide. That analysis can then be related to the right hand side of the framework to see if the current production system is the best choice to deliver the identified order winning and qualifying outputs.

The third step is to use one of the four alternatives described, in the list above, to get from the current position to where the firm wants it to be. 
As mentioned above the process of using this framework is similar to the process of using Miltenburg's (2005) production strategy framework. The framework presented here is not as comprehensive and only considers factors related to the so called process choice. However it can still be useful when working with production strategy in construction. To describe how the production strategy framework can be used in practice two scenarios derived from the case studies is used.

\subsection{Case analysis using the suggested framework}

To exemplify how the framework can be used two examples based on the data collected from the case studies is presented. The first example shows how the framework can analyse end evaluate different production systems for production of multifamily residences. The second example shows how the framework can be used as decision support when designing or redesigning production systems.

\subsubsection{Example 1: Evaluating two different production systems}

In this example two competing production systems is compared using the production strategy framework. Firstly, the characteristics of the two production systems are described to be able to position them in the classification matrix.

\section{Case A}

The concept only delivers one type of product, tower blocks with four to eight floors. Each floor consists of a combination of standard apartments with one, two, three or four rooms. Offering the customers only one house type gives a relatively high production volume of similar products.

The whole building is produced on-site, including components that normally are prefabricated, such as balconies, joists, and slabs. This concept is thereby classified as CM\&SA.

Case B

This concept only offers the customers slab blocks with two floors. The slab blocks can be built either as I-, L- or U-shaped houses. Offering the customers only one type of house (slab blocks with two floors) gives a high production volume of similar products.

Modules are produced off-site to a high level of completion. The interior of the modules are complete with floor, wallpaper, wardrobes and kitchen (appliances excluded due to risk of theft). The only activity performed on-site is the assembly. This concept is classified as MB.

Based on the case descriptions the production systems have been positioned in the classification matrix, see left part of Figure 13. 


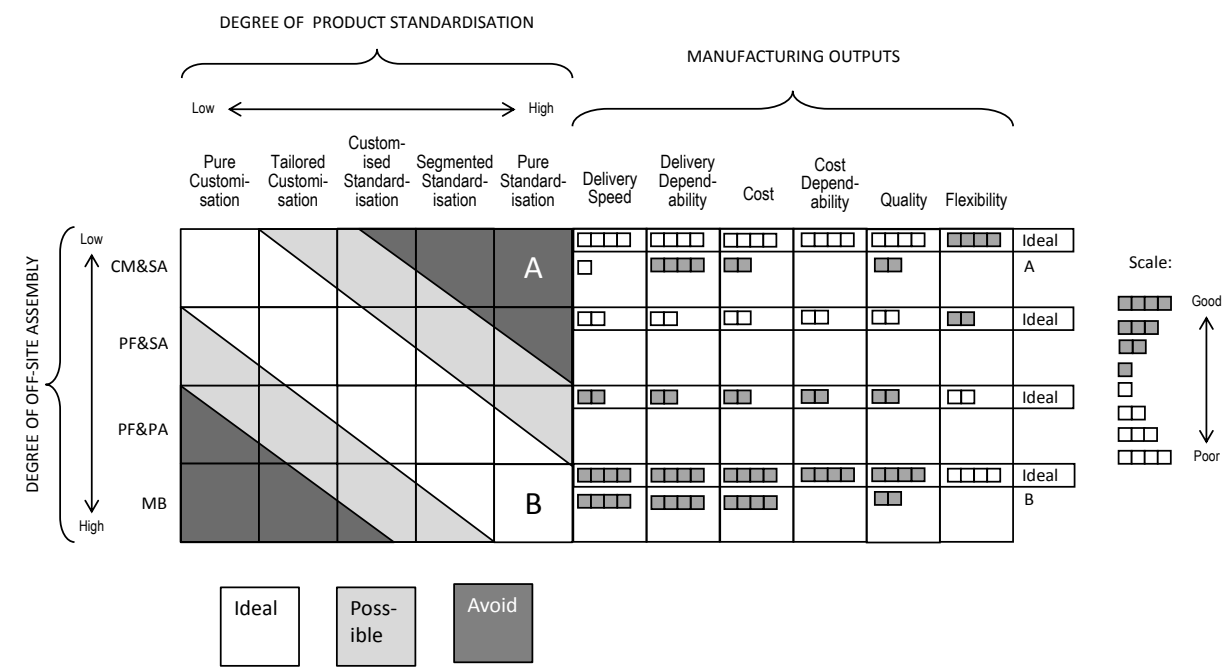

Figure 13 Comparing two different production systems in the production strategy framework

The position of the two cases reveals that Case B seems to have a match between the degree of production standardisation and the degree of off-site assembly, whilst Case A is off the diagonal since they use a production system typically used to produce customized products to produce a standardised product. The interesting question is how this affects the different concepts, i.e. production systems, ability to deliver manufacturing outputs. Some data were collected, both quantitative and qualitative, with the purpose of evaluating the production systems ability to perform. Not all of the manufacturing outputs in the framework (Figure 12) were measured but the data could be used to evaluate some of them. The result of that analysis is presented by estimating the ability of the production systems to perform in the right hand part of Figure 13.

In Figure 13 it is clear that Case A and Case B, both offer a standardized house but use different strategies when it comes to the degree of off-site assembly. Case B performs better in both production time and production cost. Since both concepts deliberately have chosen to produce a standardized product, a qualified guess would be that the order winning manufacturing output for them both are either cost or delivery with quality as a qualifying output. If that is the case, Case A is outperformed by Case B if the customer can accept the product that Case B delivers. By positioning themselves off the diagonal in the classification matrix Case A face a risk of being outperformed by other concepts positioned better in the classification matrix on all aspects of competition.

\subsubsection{Example 2: Redesigning a production system}

In this example case B is used to describe the current status of the production system, (see example 1 for a description of the product and process characteristics). The management of the firm have decided to investigate the possibility to offer the customers residences with 2-4 floors, instead of only 2 floors, and they also want to offer the customers the possibility to change the design of the house to a larger extent than in the current system. 
In this scenario the production strategy framework (Figure 12) can be used to analyse what effects the suggested market strategy changes have on the production function. Looking at the framework in Figure 13 the current status of case B is that they use a production system with a high degree of off-site production, (Modular Building) to produce a standardised product. The suggested changes of the product characteristics mean that they should decrease the degree of standardization and offer the customers a more customized product. This means that they move to the left in the classification matrix. The suggested changes are quite extensive, both increasing the number of floors and offering a higher degree of customization. If the suggestion is executed the production system would be categorized somewhere between customized standardization and tailored standardization. The new position of the production system would then be a mismatch between the current production process and the product characteristics. This is useful information and shows that the suggested changes come with a risk, visualized by the mismatch in the classification matrix. If the management of the company decides to implement the changes they will probably have to change the production process to be competitive. This can for example be done by decreasing the degree of off-site assembly meaning that they not only move to the left in the classification matrix but also up and thereby find a new position in the matrix where there is a match between product and process characteristics. 


\section{Contribution and further research}

In this final part of the thesis the managerial and scientific implications are presented and the general conclusions of the research are summarised. Finally suggestions for further research are presented.

\subsection{Purpose and contribution}

To develop a complete framework for production systems in construction turned out to be a larger task than first assumed. Therefore the result of the research, so far, is not a complete production strategy framework for the construction industry. The parts presented here, the classification matrix and the performance measurement system, are however vital pieces that have to be included in a production strategy framework. Other parts, e.g. a structured way to visualise and compare the ability of different production systems to deliver manufacturing outputs and other decision categories that should be taken into consideration are left out for future research.

\subsubsection{Scientific contribution}

The main scientific contribution in this thesis is the proposed classification matrix for production systems for the production of multifamily residences. The classification matrix can be used as a base for production strategy reasoning in the construction industry. By positioning different production systems in the classification matrix and then use the defined performance measurement system relative differences between the ability of different production systems to deliver manufacturing outputs can be exposed. The classification matrix and the defined KPIs can be used to clarify how the design of a production system affects the competitiveness.

This research contributes to traditional production strategy research by studying the project part of the product-process matrix, exemplified by the construction industry that often is left out of the scope in other studies. Knowledge about project based production systems producing products at a fixed position is useful in industries that typically use that type of production systems, e.g. the construction industry and the ship building industry.

This research also contributes to construction industry research, studying off-site production, by adapting traditional production strategy theory to a construction industry 
context. By applying production strategy theories on a construction industry context cause and effect relations concerning the production function can be explained in a logical way.

Another contribution is the defined KPIs for measuring quality, delivery (speed and dependability, cost (level and dependability) and flexibility (volume, mix and expansion). The KPIs can be used to evaluate different production systems in order to see how the characteristics of the production system affect the ability to deliver manufacturing outputs.

\subsubsection{Contribution to the construction industry}

The classification matrix developed in this research exposes that there are differences between production systems in construction and that different product characteristics must be taken into account when designing an appropriate production system. Classifying production systems for production of multifamily residences, based on the degree of product standardisation and the degree of off-site assembly, also exposes that different production systems most likely perform well in different areas of competition. The classification matrix can help companies to work with production strategy in a structured and systematic way, and to visualise the link between the market strategy and the production function of the firm. Yet, to understand this more thoroughly the matrix must be complemented with a part analysing the production systems' relative ability to deliver manufacturing outputs at competitive levels (see the right hand part of the tentative framework presented in Figure 12). To do this, KPIs for measuring Delivery, Cost, Quality and Flexibility have been defined. The classification matrix combined with the KPIs can help companies in their work with production strategy. The link between product and process characteristics and performance are visualised and this can be useful when designing a new concept for production of multifamily residences or when improving an already existing concept. For a production system to be successful it must be designed to meet the demands from the targeted market in an appropriate way. The defined KPIs can also be useful for construction companies in general in their work with continuous improvements and to follow up performance over time.

\subsection{Further research}

As mentioned earlier the research presented in this thesis does not consider all the necessary aspects of a complete production strategy framework. In this section the following suggestions for further research are given:

- For the manufacturing outputs delivery, cost and quality the defined KPIs are clear and validated empirically. For flexibility, the KPIs are more complex. There is a need to investigate how to measure process flexibility further for the framework to be complete.

- Another issue that should be investigated further is the performance evaluation part of the framework (Figure 12). From a production strategy perspective it is useful to be able to compare the relative ability of different production systems to perform in different areas of competition. From an academic perspective it would 
be interesting to see how the position in the classification matrix affects the ability of the production system to perform. This could be done by either, mapping and measuring "many" production systems and compare their relative ability to perform, or to do a longitudinal study of a production system that move from one position in the matrix to another. In such a case it would be interesting to see how the change affect the ability of the production system to perform by measuring the ability to deliver manufacturing outputs before and after the change has been implemented. To be able to do this the KPIs defined in Table 10 must be related to the system used to visualise performance in the framework, i.e. the white and black bars representing good and bad performance in Figure 12.

- For the production strategy framework to be complete, other decision categories (see Table 1) should be investigated to see how they affect both each other and the ability of the production system to perform.

Even though the classification matrix and the performance measurement system developed and presented in this thesis is not a complete production strategy framework I believe that it is a good start in the process towards a framework for production strategy in construction. 


\section{References}

Azman, M. N. A., Ahamad, M. S. S., Majid, T. A. and Hanafi, M. H. (2010). The Common Approach in Off-Site Construction Industry. Australian Journal of Basic and Applied Sciences, 4:9, 4478 - 4482.

Barlow, J., Childerhouse, P., Gann, D., Hong-Minh, S., Naim, M. and Ozaki, R. (2003). Choice and delivery in housebuilding- lessons from Japan for UK housebuilders. Building Research \& Information, 134-145.

Bassioni, H. A., Price, A. D. F. and Hassan, T. M. (2004). Performance Measurement in Construction. Journal of Management in Engineering, 20:2, 42 - 50.

Beatham, S., Anumba, C., Thorpe, T. and Hedges, I. (2004). KPIs: a critical appraisal of their use in construction. Benchmarking: An International Journal, 11:1, 93-117.

Bititci, U. S., Carrie, A. S. and Mcdevitt, L. (1997). Integrated performance measurement systems: an audit and development guide. The TQM Magazine, 9:1, 46 - 53.

Boverket (2012). Bostadsbristen ur ett marknadsperspektiv [The housing shortage from a marketing perspective]. Karlskrona.

Buffa, E. S. (1984). Meeting the competitive Challenge: Manufacturing Strategy for U.S. Companies, Dow Jones-Irwin.

Byggindustrier, S. (2013). Fakta om Byggandet [Facts about construction]. Stockholm.

Cbpp, C. B. P. P. (2002). Key Perfomance Indicators.

Cox, J. F. and Blackstone, J. H. (1998). APICS dictionary, APICS (Falls Church, VA).

Dangayach, G. S. and Deshmukh, S. G. (2001). Manufacturing Strategy - Literature Review and some Issues. International Journal of Operations \& Production Management, 21:7, 884 - 932.

Dent, R. J. and Storey, D. A. (2004). Benchmarking the performance of design activities in construction. London.

Dutt, M., Biswas, D., Arora, P. and Kar, N. (2012). Using the EFQM Model Effectively. Journal for Quality \& Participation, 35:1, 11-17.

Egan, J. (1998). Rethinking construction. London.

Eisenhardt, K. M. (1989). Building theories from case study research. Academy of Management Review, 14:4, 532-550.

Eriksson, P. E., Olander, S., Szentes, H. and Widén, K. (2013). Managing short-term efficiency and long-term development through industrialized construction. Construction Management and Economics, 1-12. 
Fahey, L. and Christensen, H. K. (1986). Evaluating the Research on Strategy Content. Journal of Management, 12:2, 167.

Ferdows, K. and Meyer, A. D. (1990). Lasting Improvements in Manufacturing Performance: In Search of a New Theory. Journal of Operations Management, 9:2, $168-184$.

Fine, C. H. and Hax, A. C. (1985). Manufacturing Strategy: A Methodology and an Illustration. Interfaces, 15:6, 28-46.

Gibb, A. G. F. (2001). Standardization and pre-assembly- distinguishing myth from reality using case study research. Construction Management and Economics, 19:3, 307-315.

Gibb, A. G. F. and Isack, F. (2003). Re-engineering through pre-assembly: client expectations and drivers. Building Research \& Information, 31:2, 15.

Hallgren, M., Olhager, J. and Schroeder, R. G. (2011). A hybrid model of competitive capabilities. International Journal of Operations \& Production Management, 31:5, 511-526.

Hayes, R. H. and Wheelwright, S. C. (1979). Link manufacturing process and product life cycles: Focusing on the process gives a new dimesion to strategy. Harvard Business Review, January-February133-140.

Hayes, R. H. and Wheelwright, S. C. (1984). Restoring our competitive edge: Competing through manufacturing, John Wiley \& Sons.

Hill, A. and Hill, T. (2009). Manufacturing Operations Strategy, Palgrave Macmillan.

Hill, T. (2000). Manufacturing Strategy Text and Cases, Hamshire, Palgrave.

Jonsson, H. and Rudberg, M. (2014a). Classification of production systems for industrialized building: a production strategy perspective. Construction Management and Economics, 32:1-2, 53-69.

Jonsson, H. and Rudberg, M. (2014b). A production system classification matrix: Matching product standardization and production system design. Norrköping.

Jonsson, H. and Rudberg, M. (2014c). Performance measurement for production systems in construction. Norrköping.

Josephson, P.-E. (2013). Produktivitetsläget i svenskt byggande 2013 [Productivity state in the Swedish construction industry 2013]. In: Sbuf (ed.). Göteborg.

Kadir, M. R. A., Lee, W. P., Jaafar, M. S., Sapuan, S. M. and Ali, A. a. A. (2006). Construction performance comparison between conventional and industrialised building systems in Malaysia. Structural Survey, 24:5, 412-424.

Kagioglou, M., Cooper, R. and Aouad, G. (2001). Performance management in construction: a conceptual framework. Construction Management and Economics, 19:1, 85-95. 
Kamar, K. a. M., Hamid, Z. A., Azman, M. N. A. and Ahamad, M. S. S. (2011). Industrialized Building System (IBS): Revisiting Issues of Definition and Classification. International Journal of Emerging Sciences 1:2, 120-132.

Kaplan, R. S. and Norton, D. P. (1992). The Balanced Scorecard - Measures That Drive Performance. Harvard Business Review, 70:1, 71 - 79.

Karlsson, C. (2009). Researching Operations Management, New York, Routledge.

Keegan, D. P., Eiler, R. G. and Jones, C. R. (1989). Are your performance measure obsolete? Management Accounting, 70:12, 45 - 50.

Kovács, G. and Spens, K. M. (2005). Abductive reasoning in logistics research. International Journal of Physical Distribution \& Logistics Management, 35:2, $132-144$.

Lampel, J. and Mintzberg, H. (1996). Customizing Customization. Sloan Management Review, 38:1, 21 - 30.

Larsson, J., Eriksson, P. E., Olofsson, T. and Simonsson, P. (2013). Industrialized construction in the Swedish infrastructure sector: core elements and barriers. Construction Management and Economics, 1-14.

Leong, G., Snyder, D. and Ward, P. (1990). Research in the Process and Content of Manufacturing Strategy. Omega International Journal of Management Science, $18: 2,109-122$.

Lind, H. and Song, H.-S. (2012). Dålig produktivitetsutveckling i byggindustrin - Ett faktum eller ett mätfel [Bad productivity growth in the construction industry - a fact or a measurement error]. In: Byggindustrier, S. (ed.). Stockholm.

Meiling, J., Backlund, F. and Johnsson, H. (2012). Managing for continuous improvement in off-site construction: Evaluation of lean management principles. Engineering, Construction and Architectural Management, 19:2, 141-158.

Miltenburg, J. (2005). Manufacturing Strategy - How to Formulate and Implement a Winning Plan, New York, Productivity Press.

Nadim, W. and Goulding, J. S. (2011). Offsite production: a model for building down barriers: A European construction industry perspective. Engineering, Construction and Architectural Management, 18:1, 82-101.

Pan, W., Gibb, A. and Dainty, A. (2007). Perspectives of UK housebuilders on the use of offsite modern methods of construction. Construction Management and Economics, 25:2, 183-194.

Pan, W., Gibb, A. G. F. and Dainty, A. R. J. (2012b). Strategies for Integrating the Use of Off-Site Production Technologies in House Building. Journal of Construction Engineering and Management, 138:11, 1331-1340.

Raynsford, N. (2000). KPI Report for The Minister for Construction. Norwich. 
Robinson, H. S., Anumba, C. J., Carrillo, P. M. and Al-Ghassani, A. M. (2005). Business performance measurement practices in construction engineering organisations. Measuring Business Excellence, 9:1, 13-22.

Rogalski, S. (2011). Flexibility Measurement in Production Systems, Handling Uncertainties in Industrial Production, London, Springer.

Rudberg, M. (2002). Manufacturing strategy: Linking Competitive Priorities, Decision Categories and Manufacturing Networks. PhD thesis, Linköping University.

Rudberg, M. (2004). Linking competitive priorities and manufacturing networks: a manufacturing strategy perspective. International Journal of Manufacturing Technology and Management, 6:1/2, 55-80.

Schmenner, R. W. and Swink, M. L. (1998). On Theory in Operations Management. Journal of Operations Management, 17:1, 97-113.

Sethi, A. K. and Sethi, S. P. (1990). Flexibility in Manufacturing: A Survey. The International Journal of Flexible Manufacturing Systems, 2289 - 328.

Skinner, W. (1969). Manufacturing - missing link in corporate strategy. Harvard Business Review, May-June136-145.

Slack, N. and Lewis, M. (2011). Operations Strategy, Harlow, Pearson Education Limeted.

Sou (2002:115). Skärpning gubbar! Om konkurrensen, kvaliteten, kostnaderna och kompetensen i byggsektorn [About competition, quality, costs and competence in construction, in Sweden] Stockholm.

Statskontoret (2009). Sega gubbar? Stockholm.

Swan, W. and Kyng, E. (2004). An Introduction to Key Performance Indicators. Manchester: Centre for Construction Innovation.

Teicholz, P., Goodrum, P. M. and Haas, C. T. (2001). U.S. Construction Labor Productivity Trends, 1970-1998. Journal of Construction Engineering \& Management, 127:5, 427.

Thuesen, C. and Hvam, L. (2011). Efficient on-site construction: learning points from a German platform for housing. Construction Innovation: Information, Process, Management, 11:3, 338-355.

Yin, R. K. (2009). Case Study Research Design and Methods, Thousand Oaks, Carlifornia Sage Publications.

Ågren, R. and Wing, R. D. (2013). Five moments in the history of industrialized building. Construction Management and Economics, 1-10. 


\section{Papers}

The articles associated with this thesis have been removed for copyright reasons. For more details about these see:

http://urn.kb.se/resolve?urn=urn:nbn:se:liu:diva-105993 